\title{
Acute and Chronic Effects of Endurance Running on Inflammatory Markers: A Systematic Review
}

\section{OPEN ACCESS}

Edited by:

Kenneth Dormer,

Liberty University, United States

Reviewed by:

Beat Knechtle,

Institute of Primary Care, University of

Zurich, Switzerland

Leonardo Alexandre Peyré-Tartaruga

Federal University of Rio Grande do

Sul (UFRGS), Brazil

*Correspondence:

Daniel A. Boullosa

daniel.boullosa@gmail.com

Specialty section:

This article was submitted to

Exercise Physiology,

a section of the journal

Frontiers in Physiology

Received: 19 July 2017 Accepted: 22 September 2017

Published: 17 October 2017

Citation:

Barros ES, Nascimento DC, Prestes J, Nóbrega OT, Córdova C, Sousa F and Boullosa DA (2017) Acute and Chronic

Effects of Endurance Running on Inflammatory Markers: A Systematic

Review. Front. Physiol. 8:779

doi: 10.3389/fphys.2017.00779

\section{Edilberto S. Barros ${ }^{1}$, Dahan C. Nascimento ${ }^{1}$, Jonato Prestes ${ }^{1}$, Otávio T. Nóbrega ${ }^{2}$, Claúdio Córdova ${ }^{1}$, Fernando Sousa ${ }^{1}$ and Daniel A. Boullosa ${ }^{1,3 *}$}

${ }^{1}$ Physical Education, Catholic University of Brasilia, Brasilia, Brazil, ${ }^{2}$ Medical Sciences, University of Brasilia, Brasilia, Brazil,

${ }^{3}$ Sport and Exercise Science, College of Healthcare Sciences, James Cook University, Townsville, QLD, Australia

In order to understand the effect of endurance running on inflammation, it is necessary to quantify the extent to which acute and chronic running affects inflammatory mediators. The aim of this study was to summarize the literature on the effects of endurance running on inflammation mediators. Electronic searches were conducted on PubMED and Science Direct with no limits of date and language of publication. Randomized controlled trials (RCTs) and non-randomized controlled trials (NRCTs) investigating the acute and chronic effects of running on inflammation markers in runners were reviewed by two researchers for eligibility. The modified Downs and Black checklist for the assesssments of the methodological quality of studies was subsequently used. Fifty-one studies were finally included. There were no studies with elite athletes. Only two studies were chronic interventions. Results revealed that acute and chronic endurance running may affect anti- and pro-inflammatory markers but methodological differences between studies do not allow comparisons or generalization of the results. The information provided in this systematic review would help practitioners for better designing further studies while providing reference values for a better understanding of inflammatory responses after different running events. Further longitudinal studies are needed to identify the influence of training load parameters on inflammatory markers in runners of different levels and training background.

Keywords: running, inflammation, marathon, half-marathon, athletes, immunology

\section{INTRODUCTION}

Running is an important natural ability of our species that has contributed to our survival and body adaptations (Bramble and Lieberman, 2004). In the Paleolithic Era, survival was dependent on hunting and gathering, and therefore it has been suggested that the ancient physical activity pattern included mostly prolonged, low-intensity physical activities, including endurance running, interspersed with high-intensity bursts of activity (O'Keefe et al., 2010; Boullosa et al., 2013). Nowadays, endurance running is probably the most popular sport worlwide and it is practiced for recreational, health and competitive purposes (Chiampas and Goyal, 2015).

There is a close link between endurance running and the activity of the immune system. The importance of this relationship has led to important investigations over the last decades. Previously, Peters and Bateman (1983) identified an increased prevalence of upper respiratory tract infection (URTI) in 150 runners following a $56.0 \mathrm{~km}$ ultramarathon. Subsequently, specialized literature 
has suggested that even highly trained individuals, when subjected to frequent strenuous exercise, could develop a proinflammatory condition that favors the onset of a number of health problems, including damage to myocardial cells and connective tissues, overload of the atria and right ventricle, coronary artery disease (CAD), and coronary artery calcification among others (Peters and Bateman, 1983; Febbraio and Pedersen, 2005; Petersen and Pedersen, 2005; Zaldivar et al., 2006; Mohlenkamp et al., 2007; Hubble et al., 2009; Nieman, 2009; Meeusen et al., 2013; O'Keefe and Lavie, 2013; Taylor et al., 2014). However, little is known about whether the development of these chronic pathologies is the result of an excess of training volume, intensity, or both, associated with an insufficient recovery, which often promotes an increased susceptibility to infections and subsequent reduction in performance (Smith, 2004; Zaldivar et al., 2006; Hubble et al., 2009). Furthermore, systematic and non-systematic inflammation after running might be related with functional overreaching (Steinacker et al., 2004). In contrast, it has been suggested that periodised training with adequate recovery may be associated with positive adaptations including an adequate balance between pro-inflammatory and anti-inflammatory responses (Febbraio and Pedersen, 2005; Petersen and Pedersen, 2005; Zaldivar et al., 2006).

A growing body of evidence highlights the importance of studying inflammation promoted by endurance running as a factor which is linked to the physiopathology of a number of cardiovascular diseases (Mohlenkamp et al., 2007). It has also been suggested a link between myocardial damage and small thrombotic or even atherosclerotic emboli following a marathon, or after a quick session of exercise, accompanied by a transient monocytosis (about $2 \mathrm{~h}$ ) (Walsh et al., 2011). The tissue factor is known as the key initiator of coagulation, and is highly dependent on vascular injury and mediators of inflammation such as tumor necrosis factor alpha (TNF- $\alpha$ ), which has been reported to increase during and predominantly after marathon running (O’Brien, 2012; Gill et al., 2015b).

Contrary to other endurance sports, eccentric muscle contractions play a key role in running exercises, leading up to the occurrence of different levels of damage in muscle, connective and bone tissues (Suzuki et al., 2003; Jarvinen et al., 2013). The repair of these tissues involves the presence of inflammatory cells into the damaged site, which stimulates the release of proinflammatory cytokines such as TNF- $\alpha$ and interleukin-1 beta (IL-1 $\beta$ ), thus triggering inflammation (Nieman et al., 1989, 1990). However, little is known about the impact of this chronic cycle tissue damage and repair in runners.

On the other hand, it is also important to emphasize that signaling promoted by repeated muscle contractions as in running, stimulates the production of anti-inflammatory mediators by myocytes, especially interleukin-6 (IL-6), which acts as an inhibitor of pro-inflammatory cytokines such as TNF- $\alpha$ by stimulating the production of its soluble receptor antagonists (Pedersen, 2013). In addition, IL-6 also stimulates the production of interleukin-10 (IL-10) and interleukin-1 receptor antagonist (IL-1ra), generating an anti-inflammatory environment which may counterbalance the pro-inflammatory responses associated to repetitive eccentric actions (Pedersen and Febbraio, 2012).
Despite the growing body of evidence regarding the effects of endurance running on inflammation, the link between transient acute responses and chronic adaptations needs to be addressed (Gleeson, 2007). This information would be important to shed light on the possible role of the inflammatory milieu in the pathophysiology of a number of diseases, especially the cardiovascular ones. Thus, the aim of this systematic review was to investigate the effects of different doses (i.e., training and competitive loads) of endurance running on the acute and chronic inflammatory responses, and the immune effects of this practice on runners of different levels and training backgrounds.

\section{METHODS}

\section{Search Strategy}

A systematic review was conducted and the recommendations from the Preferred Reporting Itens for Systematic Review and Meta-Analyses (PRISMA) were considered (Liberati et al., 2009). The search strategies were reported to ensure the integrity of the results and allow the updating using the same methods to bring emerging evidence into the review. The Boolean and proximity operators were used and the search strategy was correctly adapted for each database used (Table 1) (Sampson et al., 2008, 2009). Studies were identified by searching the following electronic databases: PubMED/MEDLINE (via National Library of Medicine) (2000-2017) and Science Direct (Elsevier) (2000-2017). The last search was conducted in February 2017.

Once the abstracts were reviewed, the complete versions of the papers that met the criteria were obtained. In addition, the reference lists of the papers that fulfilled the inclusion criteria were analyzed for identification of additional studies. The exclusion of studies with irrelevant content and duplicates was carried out after the title, abstract and full-text were read.

\section{Definition of Terms}

An "athlete" was defined according to the Medical Subject Headings (MeSH) and was considered to be an individual who has developed skills, physical fitness and strength, or who has participated in sports running (MeSH, 2015). We have considered the definition proposed by Stirling and Kerr (2006) that defines a "recreational athlete" as being an individual who plays on a sports team at an amateur level, works out 14 times a week, does not train and compete nationally or internationally, and does not train for the same activity for more than $8 \mathrm{~h}$ per week. Novice runners were those individuals who had not been running on a regular basis in the previous 12 months $(10 \mathrm{~km}$ total in all training sessions in the previous 12 months), and recreational runners were considered as individuals running a mean of $24.94 \mathrm{~km}$ /week (Videbaek et al., 2015).

The following thesaurus terms registered in the database from MeSH were also used: "running," "aerobic exercise," "inflammation," and "cytokines." These terms were associated with the free terms "recreational runners," "novice runners," "marathon runners," and "ultramarathon." 
TABLE 1 | Search strategies.

\begin{tabular}{|c|c|c|c|}
\hline Database & Search strategy & Hits & $\begin{array}{l}\text { No. }(\%) \text { of trials } \\
\text { finally selected }\end{array}$ \\
\hline \multirow{3}{*}{$\begin{array}{l}\text { PubMED/MEDLINE-via national library of } \\
\text { medicine }\end{array}$} & 1. Inflammation AND aerobic exercise AND runners; & 128 & 50 \\
\hline & 2. Cytokines AND runn ${ }^{\star}$ AND (marathon runners or novice runners); & 64 & \\
\hline & & Total: 192 & \\
\hline $\begin{array}{l}\text { Other sources (reference lists of the papers that } \\
\text { fulfilled the inclusion criteria were analyzed for } \\
\text { the identification of additional studies) }\end{array}$ & & Total: 19 & 6 \\
\hline
\end{tabular}

*Truncation or wildcard.

\section{Inclusion and Exclusion Criteria}

The inclusion criteria were as follows: randomized controlled trials (RCTs) and non-randomized controlled trials (NRCTs); studies investigating the acute and chronic effects of running on markers of inflammation in marathon runners, recreational runners and novice runners; the terms runners, marathon runners, recreational runners and novice runners should be cited in the paper; only healthy participants; only full-text article citations with no restriction on languages; with individuals aged over 19 as the World Health Organisation (WHO) defines adolescence as the period in human growth and development that occurs between childhood and adulthood, from ages 10-19 (WHO, 2015) ${ }^{1}$. Meeting abstracts, unpublished data, observational studies, review articles, studies using walking and jogging as independent variables, and studies on the effects of any kind of supplements on running, diet restrictions, use of devices (e.g., equipment, compression garments), comparisons between running and other sports, and effects of environmental conditions (ex. dry and hot) were excluded.

\section{Outcome Measures}

The outcome measures assessed for acute and chronic effects of marathon and recreational running were interleukin (IL): IL-6, IL-10, IL-8, IL-1ra, IL-1 $\beta$, IL-2 and IL-12, TNF- $\alpha$, C reactiveprotein (CRP), interferon-gamma (IFN- $\gamma)$, soluble receptors, and transformation growth factor-beta (TGF- $\beta$ ). These mediators were chosen after an initial analysis and review of the literature. They were identified as the main outcomes in studies published with marathon runners, recreational runners and novice runners (Nieman et al., 2005; Santos et al., 2007; Scott et al., 2011; Abbasi et al., 2013; Jee et al., 2013; Shin and Lee, 2013).

\section{Quality Assessment}

The quality and assessment of all eligible articles was evaluated using a modified version of the Downs and Black checklist (Downs and Black, 1998). Disagreements between authors were discussed and subsequently solved. This modified version consists of 27 objective questions (Downs and Black, 1998).

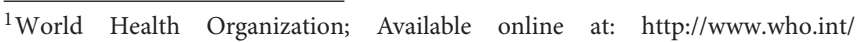
maternal_child_adolescent/topics/adolescence/dev/en/ (Acessed November 1, 2015).
}

\section{RESULTS}

\section{Research Strategy}

Results of the research strategy are presented in Figure $\mathbf{1 .}$ Initially, 60 studies were selected, with 51 studies being finally included according to the inclusion/exclusion criteria. Nine studies were excluded as follows: one study was excluded due to the use of heat stress, three because the subjects were adolescents, one following the reading of the full paper, two because of comparison with other sporting activities, and one because of medication use; in addition, one paper was not available in fulltext version (Saravia et al., 2010). A total of 49 studies verified the acute effect of running on inflammation and two studies focused on the chronic effects.

\section{Methodological Quality Assessment}

Quality assessment of the studies according to the modified Downs and Black scale is summarized in Table 2. One important finding was that characteristics of the patients' included were not cleary described in 32 studies. Important adverse events and description of patients' characteristics lost to follow-up was not reported in 34 and 32 studies, respectively. None of the studies were randomized controlled trials and power was provided in 4 studies (Table 2).

\section{Characteristics of the Studies and Summary of Outcome Measures}

An overview of the studies' characteristics is provided in Table 3 with sample size, age, sex, and exercise protocols. A summary of outcome measures in selected studies is presented on Table 4.

The 51 studies included resulted in a total of 1,421 subjects, of whom 163 were female and 1,234 males; 24 subjects were not identified by sex in one study (Neidhart et al., 2000). All trials provided age ranges for the subjects and the mean age was 39.16 years.

The common protocols adopted included marathon in 17 studies, ultra-marathon in 22, half-marathon in three studies, different distance protocols $(42.195,21.1,12,10 \mathrm{~km}$ and treadmill) in seven studies, and chronic training only in two studies (see Table 3). 


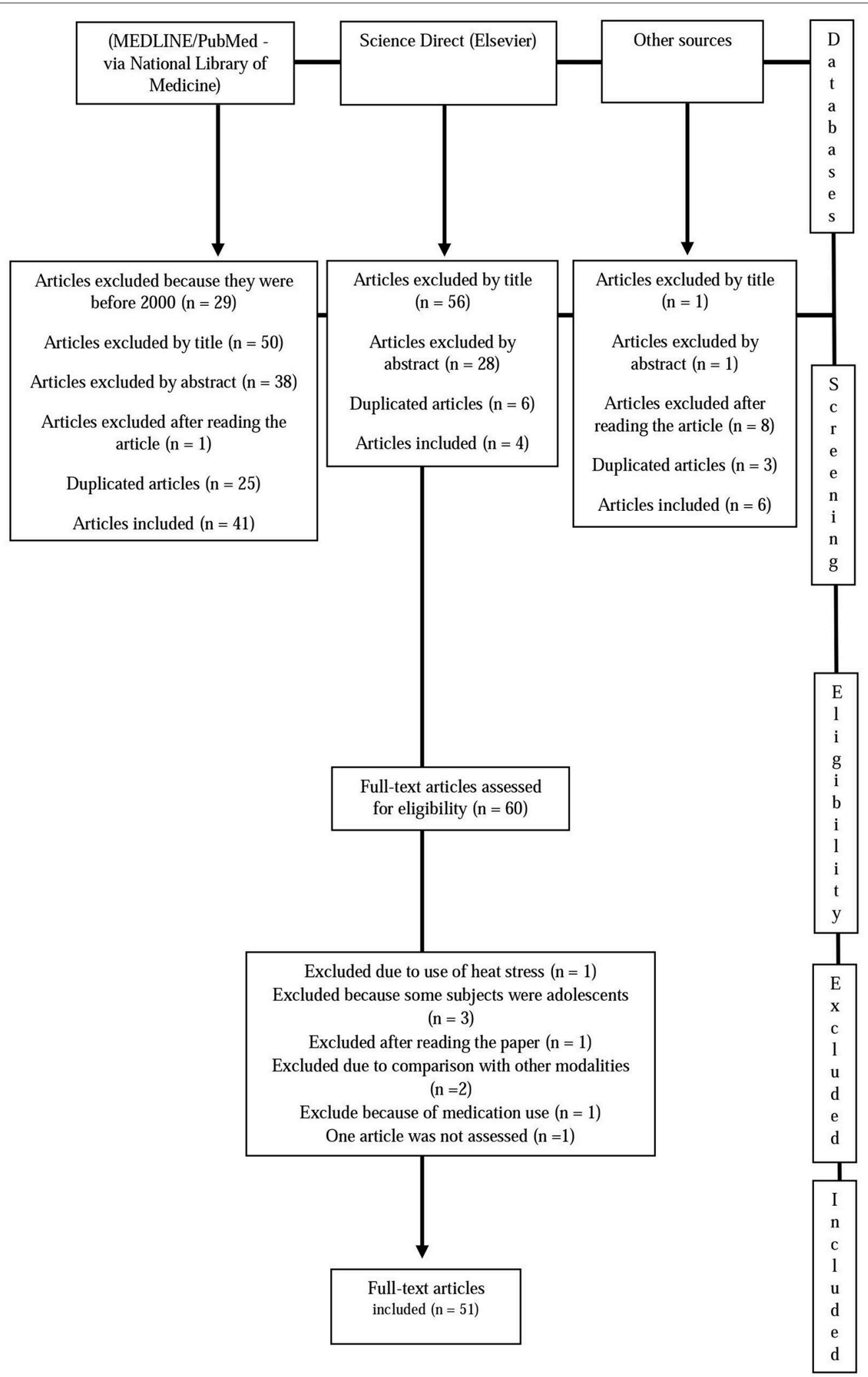

FIGURE 1 | Summary of search results. 


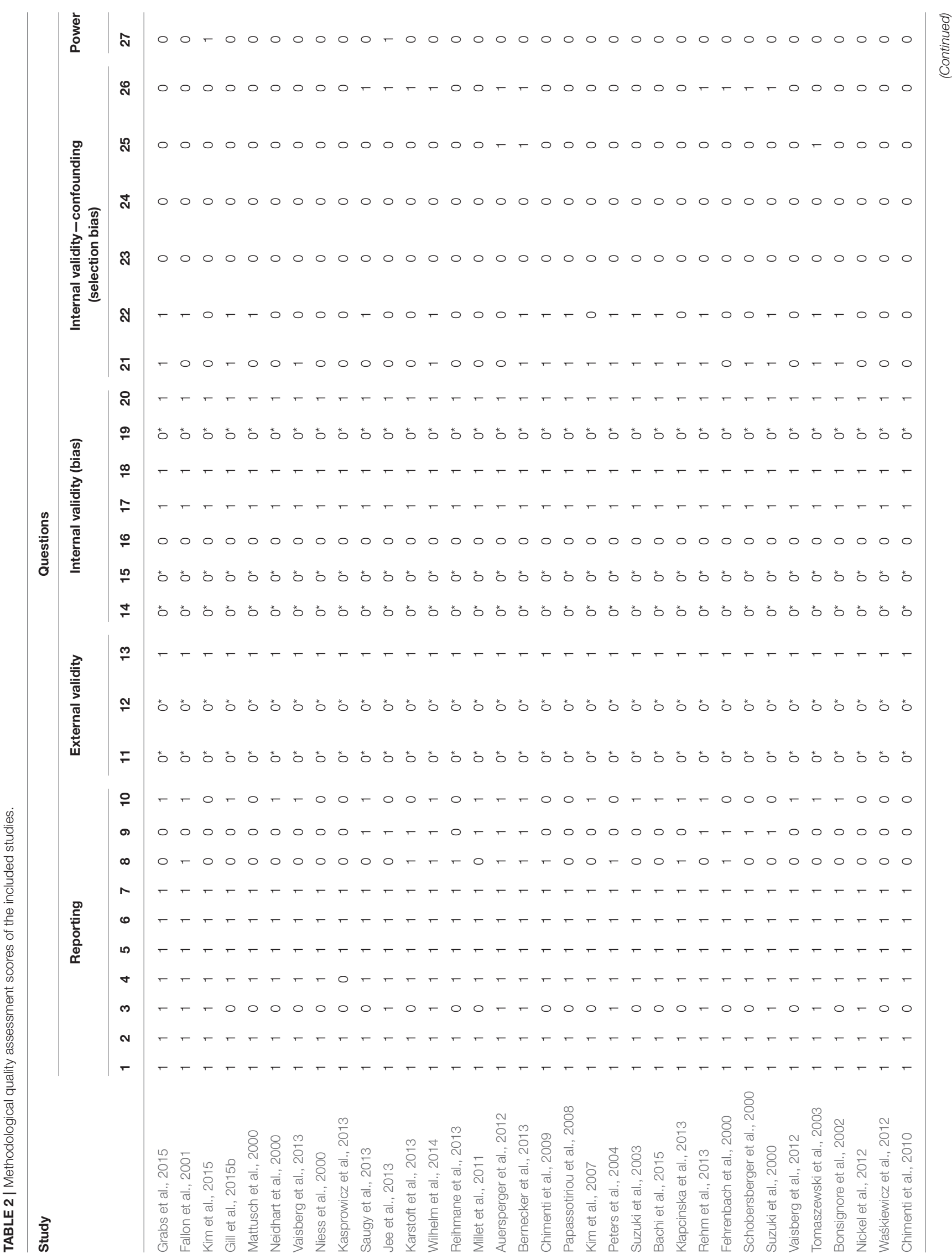




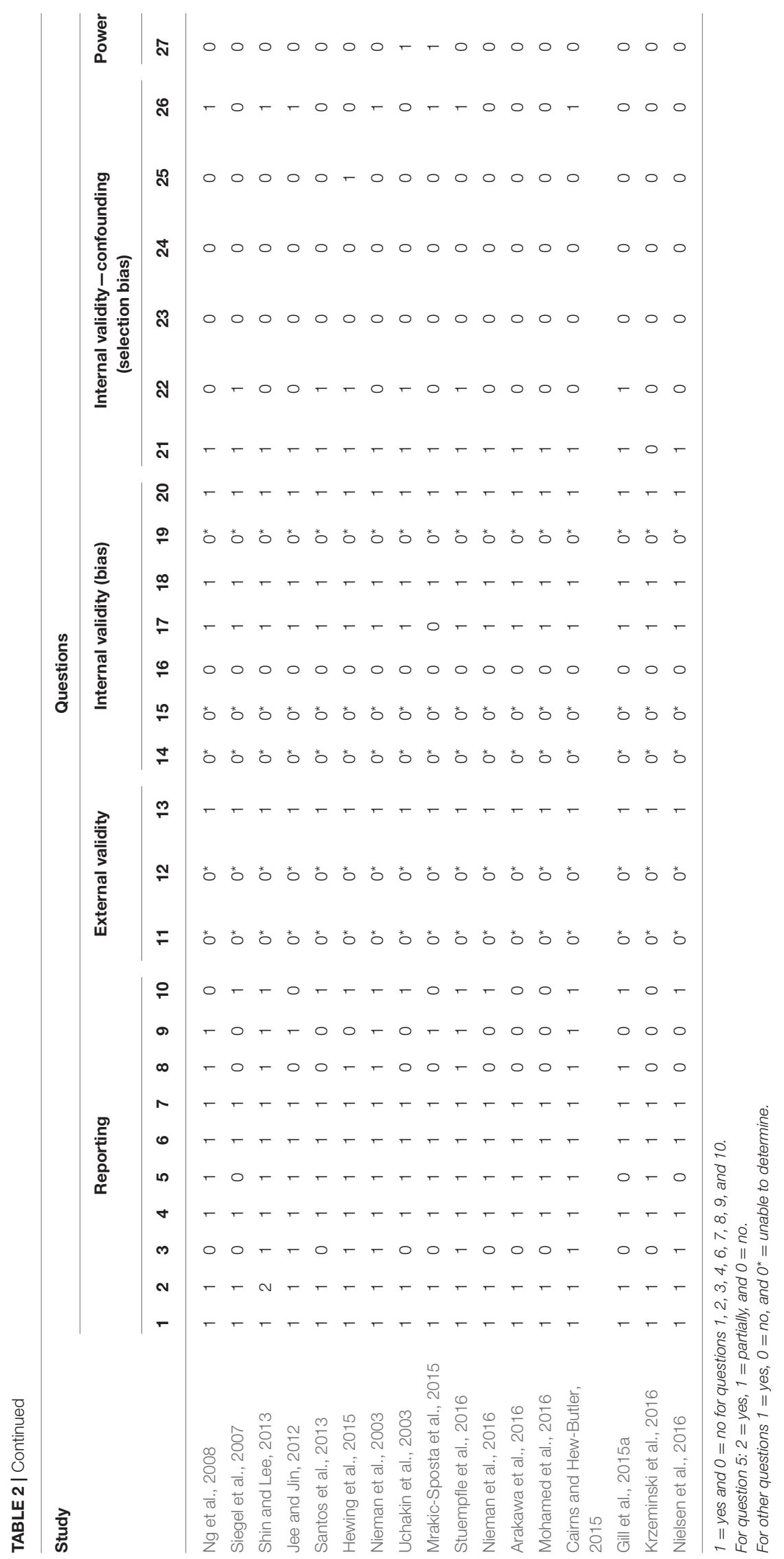


TABLE 3 | Characteristics of the studies.

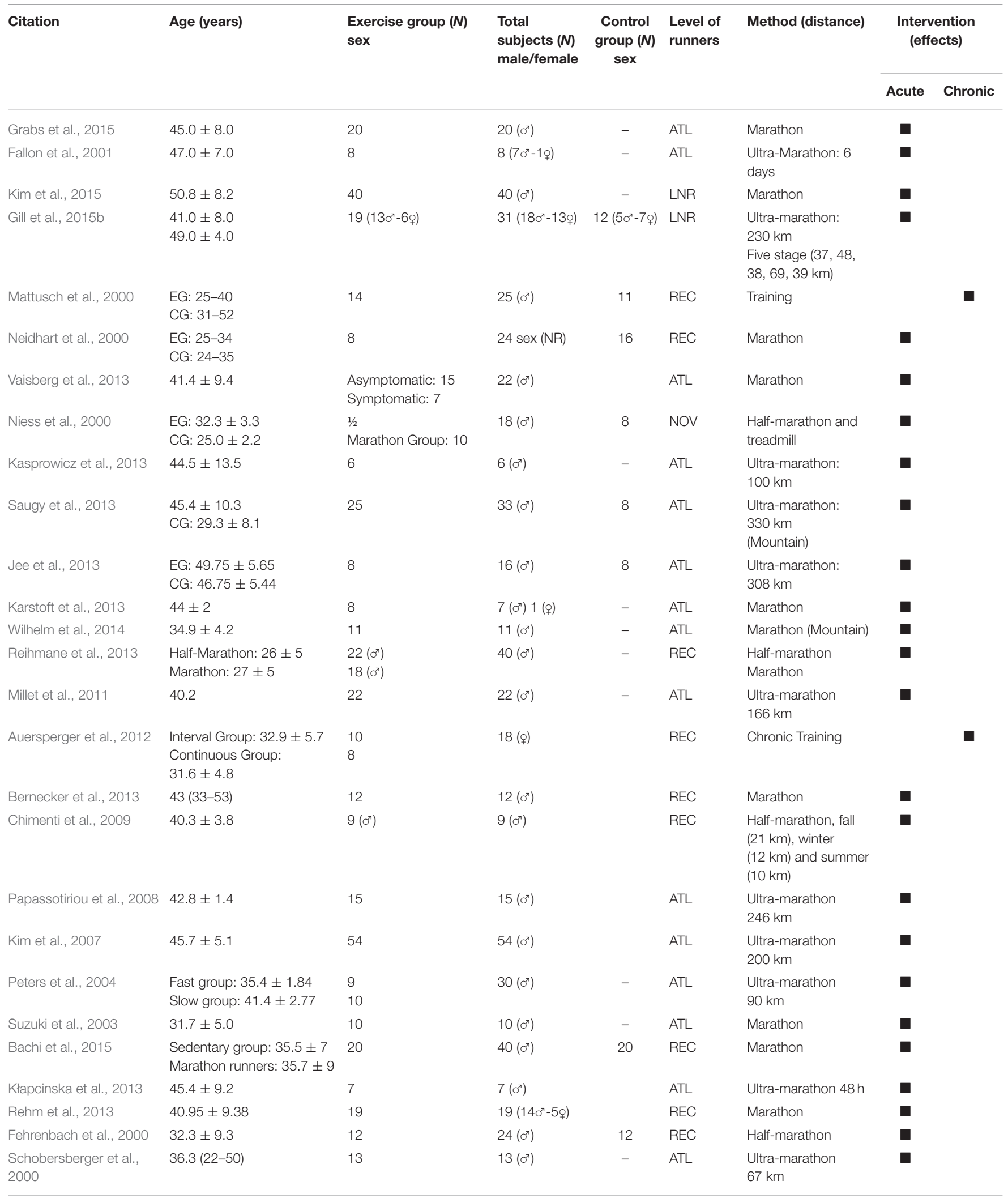


TABLE 3 | Continued

\begin{tabular}{|c|c|c|c|c|c|c|c|c|}
\hline \multirow[t]{2}{*}{ Citation } & \multirow[t]{2}{*}{ Age (years) } & \multirow[t]{2}{*}{$\begin{array}{l}\text { Exercise group }(N) \\
\text { sex }\end{array}$} & \multirow{2}{*}{$\begin{array}{l}\text { Total } \\
\text { subjects }(N) \\
\text { male/female }\end{array}$} & \multirow{2}{*}{$\begin{array}{l}\text { Control } \\
\text { group }(N) \\
\text { sex }\end{array}$} & \multirow[t]{2}{*}{$\begin{array}{l}\text { Level of } \\
\text { runners }\end{array}$} & \multirow[t]{2}{*}{ Method (distance) } & \multicolumn{2}{|c|}{$\begin{array}{l}\text { Intervention } \\
\text { (effects) }\end{array}$} \\
\hline & & & & & & & Acute & Chronic \\
\hline Suzuki et al., 2000 & $21-39$ & 16 & $16\left(0^{\top}\right)$ & - & ATL & Marathon & $\mathbf{\square}$ & \\
\hline Vaisberg et al., 2012 & $\begin{array}{l}\text { Sedentary Group: } 37.5 \pm 4 \\
\text { Athletes Group: } 38 \pm 7\end{array}$ & 14 & $42\left(0^{7}\right)$ & 28 & REC & Marathon & $\mathbf{\square}$ & \\
\hline Waśkiewicz et al., 2012 & $43.0 \pm 10.8$ & 14 & $14\left(0^{7}\right)$ & - & ATL & Ultra-marathon $24 \mathrm{~h}$ & $\mathbf{\square}$ & \\
\hline Chimenti et al., 2010 & NR & 15 & $15\left(0^{7}\right)$ & - & ATL & Half-marathon & $\mathbf{\square}$ & \\
\hline Ng et al., 2008 & $25(21-32)$ & 30 & $30\left(0^{7}\right)$ & - & $N R L$ & Half-marathon & $\mathbf{\square}$ & \\
\hline Siegel et al., 2007 & $49 \pm 10$ & 33 & $33\left(0^{7}\right)$ & - & $N R L$ & Marathon & $\mathbf{\square}$ & \\
\hline Shin and Lee, 2013 & $52.8 \pm 5.0$ & 18 & $18\left(0^{\top}\right)$ & - & ATL & $\begin{array}{l}\text { Ultra-marathon } \\
308 \mathrm{~km}\end{array}$ & $\mathbf{\square}$ & \\
\hline Jee and Jin, 2012 & $49.5(47-54)$ & 24 & $24\left(\sigma^{7}\right)$ & - & ATL & $\begin{array}{l}\text { Ultra-marathon } \\
308 \mathrm{~km}\end{array}$ & $\mathbf{\square}$ & \\
\hline Santos et al., 2013 & $\begin{array}{l}\text { Athletes } 35.2 \pm 3.6 \\
\text { Non-athletes } 31.6 \pm 2.3\end{array}$ & Athletes: 15 & $27\left(0^{7}\right)$ & $\begin{array}{l}\text { Non- } \\
\text { athletes: } \\
12\end{array}$ & ATL & Marathon & $\mathbf{\square}$ & \\
\hline Stuempfle et al., 2016 & $\begin{array}{l}\text { With nausea: } 44.3 \pm 10.5 \\
\text { Without nausea: } 41.8 \pm 9.1\end{array}$ & 20 & $\left(150^{x}-05 \%\right)$ & - & ATL & $\begin{array}{l}\text { Ultra-Marathon } \\
161-\mathrm{km}\end{array}$ & $\mathbf{\square}$ & \\
\hline Nieman et al., 2016 & $22-45$ & 20 & $\left(100^{x}-10 \%\right)$ & - & ATL & $\begin{array}{l}1.5 \mathrm{~h} \text { on treadmills at } \\
\sim 70 \% \mathrm{VO}_{2} \mathrm{max} \\
\text { followed by } 30 \mathrm{~min} \\
\text { of downhill running }\end{array}$ & घ & \\
\hline Arakawa et al., 2016 & $52.1 \pm 12.1$ & 25 & $25\left(0^{7}\right)$ & - & ATL & Ultra-Marathon & $\mathbf{\square}$ & \\
\hline Mohamed et al., 2016 & $\begin{array}{l}\text { SS: } 23.9 \pm 4.20 \\
\text { LDR: } 22.70 \pm 3.70 \\
\text { MDR: } 21 \pm 1.80\end{array}$ & $\begin{array}{l}\operatorname{SS}(n=8) \\
\operatorname{LDR}(n=9) \\
\operatorname{MDR}(n=8)\end{array}$ & $24\left(0^{7}\right)$ & - & ATL & $\begin{array}{l}\text { Incremental Event } \\
\text { (VAMEVAL test) } \\
\text { Supra-Maximal } \\
\text { Exhausting Race } \\
\text { (Limited-Time Test) }\end{array}$ & $\mathbf{\square}$ & \\
\hline $\begin{array}{l}\text { Cairns and Hew-Butler, } \\
2015\end{array}$ & $43.7 \pm 9.8$ & $\begin{array}{l}\text { Normonatremic: } 5 \\
\text { Hyponatremic: } 10\end{array}$ & $15\left(12 \sigma^{7} 3 o p\right)$ & - & ATL & $\begin{array}{l}100 \mathrm{~km}(103.7 \mathrm{~km}) \\
\text { and } 100 \text { miles } \\
(173.7 \mathrm{~km})\end{array}$ & $\mathbf{\square}$ & \\
\hline Gill et al., 2015a & $40 \pm 7$ & 17 & $\left(140^{r}-03 \%\right)$ & $\begin{array}{c}17 \\
\left(04 \sigma^{\top}-08 \%\right)\end{array}$ & ATL & Ultra-Marathon 24-H & $\mathbf{\square}$ & \\
\hline
\end{tabular}


TABLE 3 | Continued

\begin{tabular}{|c|c|c|c|c|c|c|c|c|}
\hline Citation & Age (years) & $\begin{array}{l}\text { Exercise group }(N) \\
\text { sex }\end{array}$ & $\begin{array}{l}\text { Total } \\
\text { subjects }(N) \\
\text { male/female }\end{array}$ & $\begin{array}{l}\text { Control } \\
\text { group }(N) \\
\text { sex }\end{array}$ & $\begin{array}{l}\text { Level of } \\
\text { runners }\end{array}$ & Method (distance) & \multicolumn{2}{|c|}{$\begin{array}{l}\text { Intervention } \\
\text { (effects) }\end{array}$} \\
\hline Krzeminski et al., 2016 & $30 \pm 1.0$ & 09 & $09\left(0^{7}\right)$ & - & ATL & $\begin{array}{l}\text { Ultra-Marathon } \\
100 \mathrm{~km}\end{array}$ & $\mathbf{\square}$ & \\
\hline
\end{tabular}

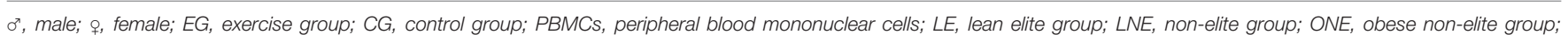

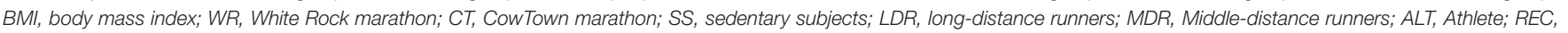
Recreational; NOV, Novice; Not reportable level (No reported details by authors), NRL; LNR, Level not reported.

\section{DISCUSSION}

The aim of this systematic review was to analyze studies that verified the effects of different endurance running exercises on acute and chronic inflammatory responses in runners of different training background. The present systematic review allows an initial understanding of this issue. It seems that acute and chronic endurance running may affect anti- and proinflammatory markers. However, important differences between studies in terms of methods as well as in runners' charactersitics do not allow appropriate comparison or generalization of results.

\section{Inflammatory Markers}

The timing in data collection could be considered an important limiting factor for adequate comparisons, given the heterogeneity observed across the reported acute (i.e., 5-20 min) (Fallon et al., 2001; Kim et al., 2007; Vaisberg et al., 2013; Grabs et al., 2015) and delayed responses ( $24 \mathrm{~h}$ to 8 days) (Uchakin et al., 2003; Siegel et al., 2007; Hewing et al., 2015). This is not a simple issue given the different kinetics and biological availability of the molecules considered as IL-6 and CRP (Kasprowicz et al., 2013; Reihmane et al., 2013). Of note, some inflammatory markers (e.g., monocyte chemoattractant protein-1, granulocyte colonystimulating factor) (Suzuki et al., 2003) have not been included in the current review. Further studies should elaborate appropriate study designs that consider both the appropriateness of the inflammatory markers selected as well as their kinetics.

\section{Runners' and Training Load Characteristics} Another important confounding factor is the different experience of runners. Thus, 26 studies (4 studies with male and female participants, and 15 studies with only male participants) reported a range of 4-17.5 years of experience with competitions (e.g., marathon, and ultra-marathon experience) (Schobersberger et al., 2000; Fallon et al., 2001; Nieman et al., 2003, 2016; Suzuki et al., 2003; Tomaszewski et al., 2003; Kim et al., 2007, 2015; Millet et al., 2011; Jee and Jin, 2012; Vaisberg et al., 2012, 2013; Waśkiewicz et al., 2012; Bernecker et al., 2013; Jee et al., 2013; Karstoft et al., 2013; Kasprowicz et al., 2013; Kłapcinska et al., 2013; Saugy et al., 2013; Shin and Lee, 2013; Wilhelm et al., 2014; Grabs et al., 2015; Hewing et al., 2015; MrakicSposta et al., 2015; Krzeminski et al., 2016; Mohamed et al., 2016). However, 25 studies did not report this information (Fehrenbach et al., 2000; Mattusch et al., 2000; Neidhart et al., 2000; Niess et al., 2000; Suzuki et al., 2000; Bonsignore et al., 2002; Uchakin et al., 2003; Peters et al., 2004; Siegel et al., 2007; Ng et al., 2008; Papassotiriou et al., 2008; Chimenti et al., 2009, 2010; Auersperger et al., 2012; Nickel et al., 2012; Rehm et al., 2013; Santos et al., 2013; Bachi et al., 2015; Gill et al., 2015b; Arakawa et al., 2016; Nielsen et al., 2016; Stuempfle et al., 2016; Vernillo et al., 2017). This is not a trivial issue given that training experience of runners could have a potentially additive effect to the influence of runners' age on inflammation that warrants further research. Besides, only 34 articles especified the training preparation $(\mathrm{km} /$ week that ranged between 21.4 and 161 and time that ranged between 3.9 and $10 \mathrm{~h} /$ week) of runners before races (Fehrenbach et al., 2000; Mattusch et al., 2000; Niess et al., 2000; Suzuki et al., 2000, 2003; Fallon et al., 2001; Bonsignore et al., 2002; Nieman et al., 2003, 2016; Tomaszewski et al., 2003; Uchakin et al., 2003; Peters et al., 2004; Chimenti et al., 2009; Millet et al., 2011; Auersperger et al., 2012; Jee and Jin, 2012; Nickel et al., 2012; Vaisberg et al., 2012, 2013; Waśkiewicz et al., 2012; Bernecker et al., 2013; Karstoft et al., 2013; Kłapcinska et al., 2013; Rehm et al., 2013; Reihmane et al., 2013; Santos et al., 2013; Shin and Lee, 2013; Wilhelm et al., 2014; Bachi et al., 2015; Grabs et al., 2015; Hewing et al., 2015; MrakicSposta et al., 2015; Arakawa et al., 2016; Krzeminski et al., 2016). Furthermore, only two studies cited the control of intensity during training (Mattusch et al., 2000; Auersperger et al., 2012). This aspect would be important for a better understanding of the relationship between running and inflammation from a doseresponse perspective. For instance, higher values for IL-6 after a limited-time test were observed in sedentary individuals when compared to long- and middle-distance runners, but with no differences between groups for TNF- $\alpha$ (Mohamed et al., 2016). Given the growing popularity of races that last various days, further studies are warranted to elucidate if chronic exposure to high volumes of endurance running are detrimental for health. From an evolutionary perspective, this is an interesting topic given that daily running volumes of modern huntergatherers are far below (e.g., $\sim 10-15 \mathrm{~km}$ ) (O'Keefe et al., 2010; 
TABLE 4 | Summary of outcome measures.

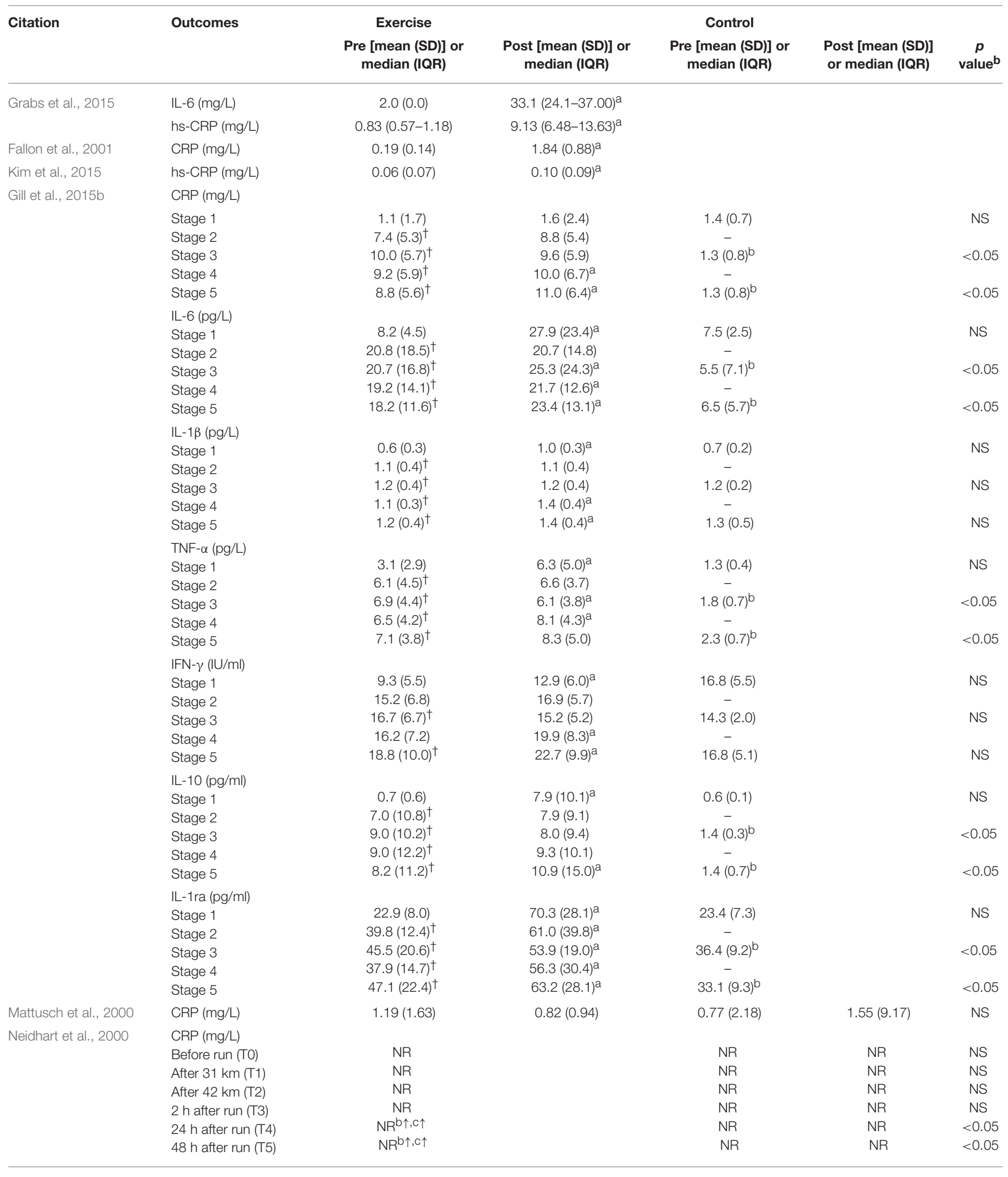


TABLE 4 | Continued

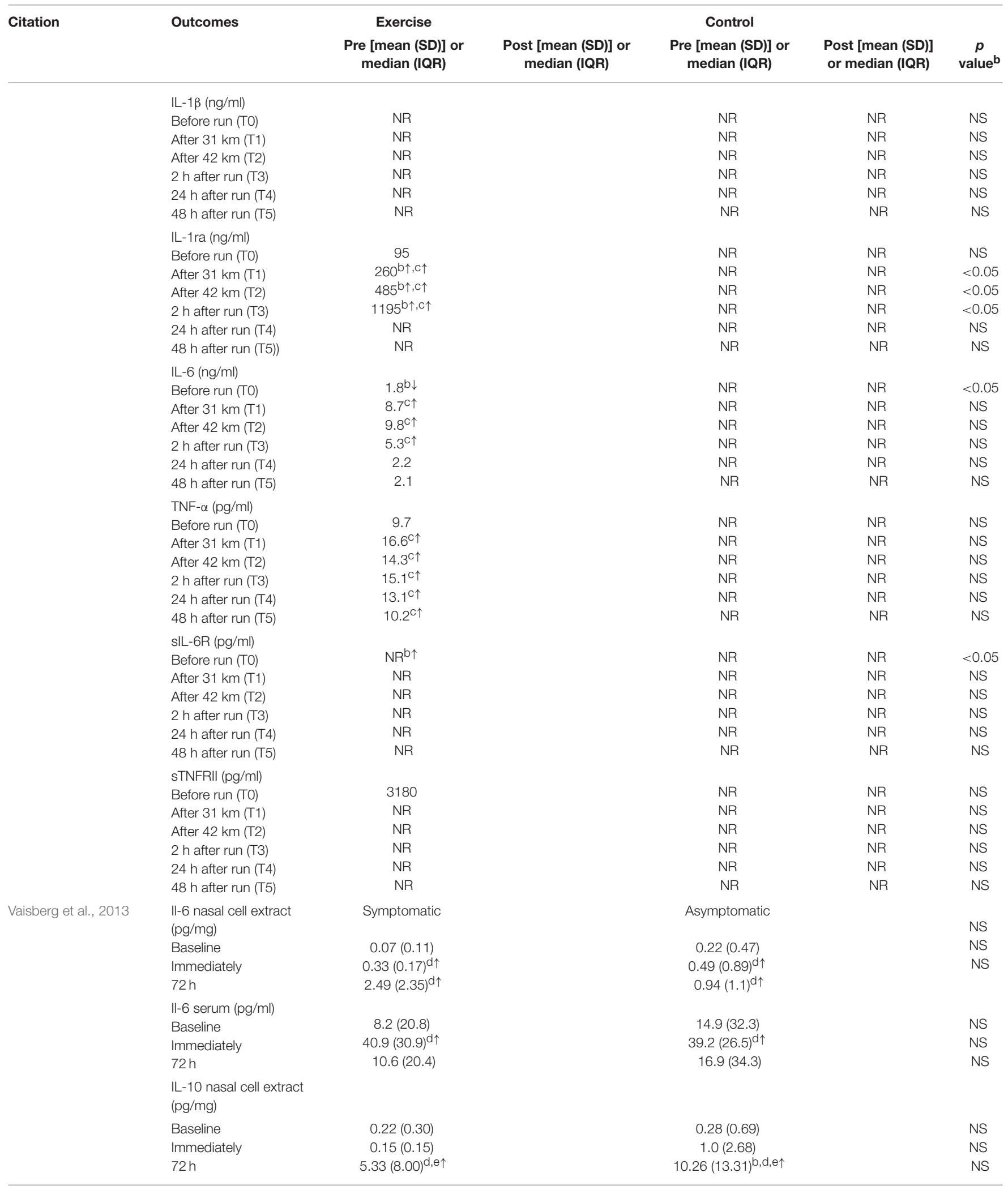


TABLE 4 | Continued

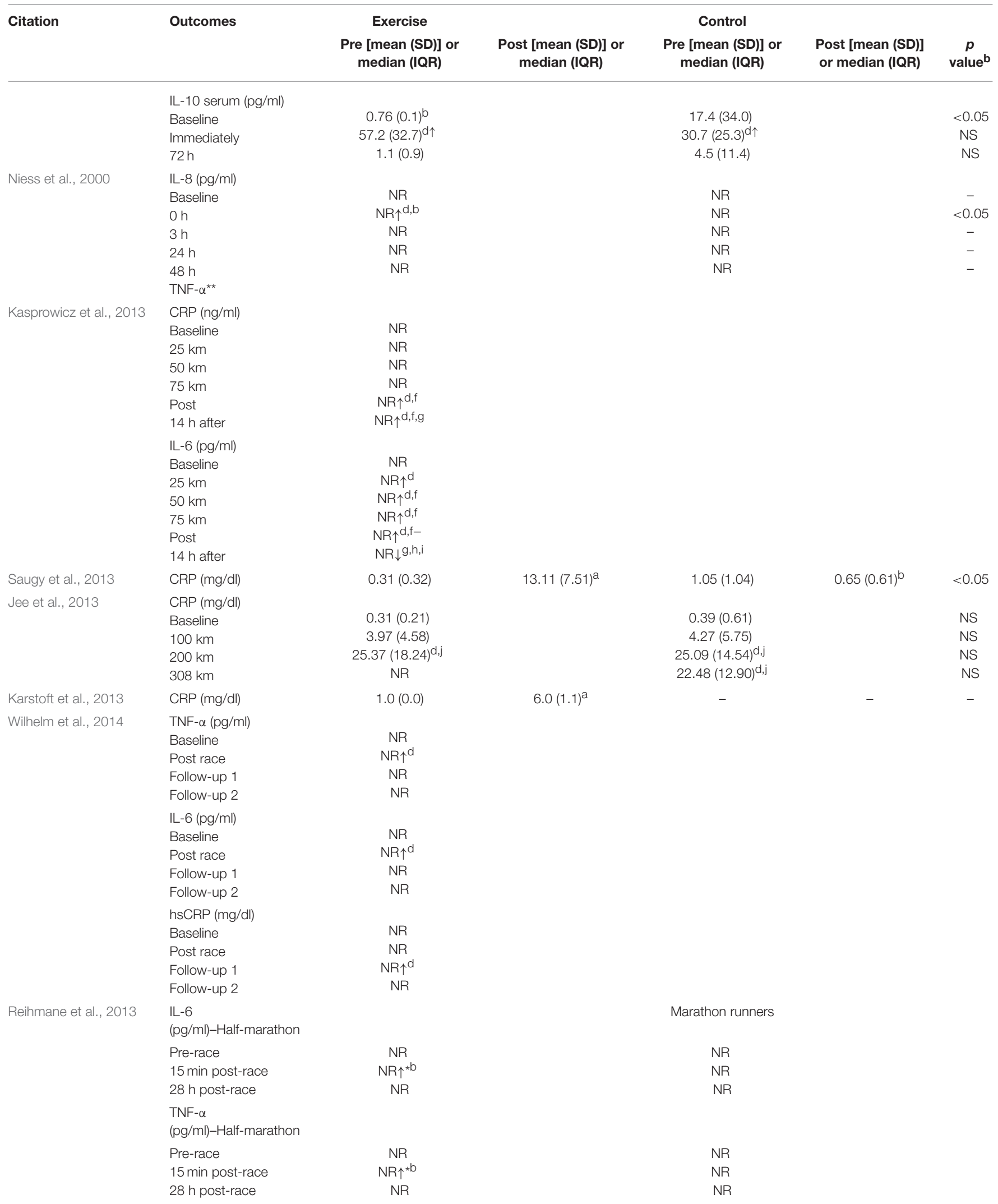


TABLE 4 | Continued

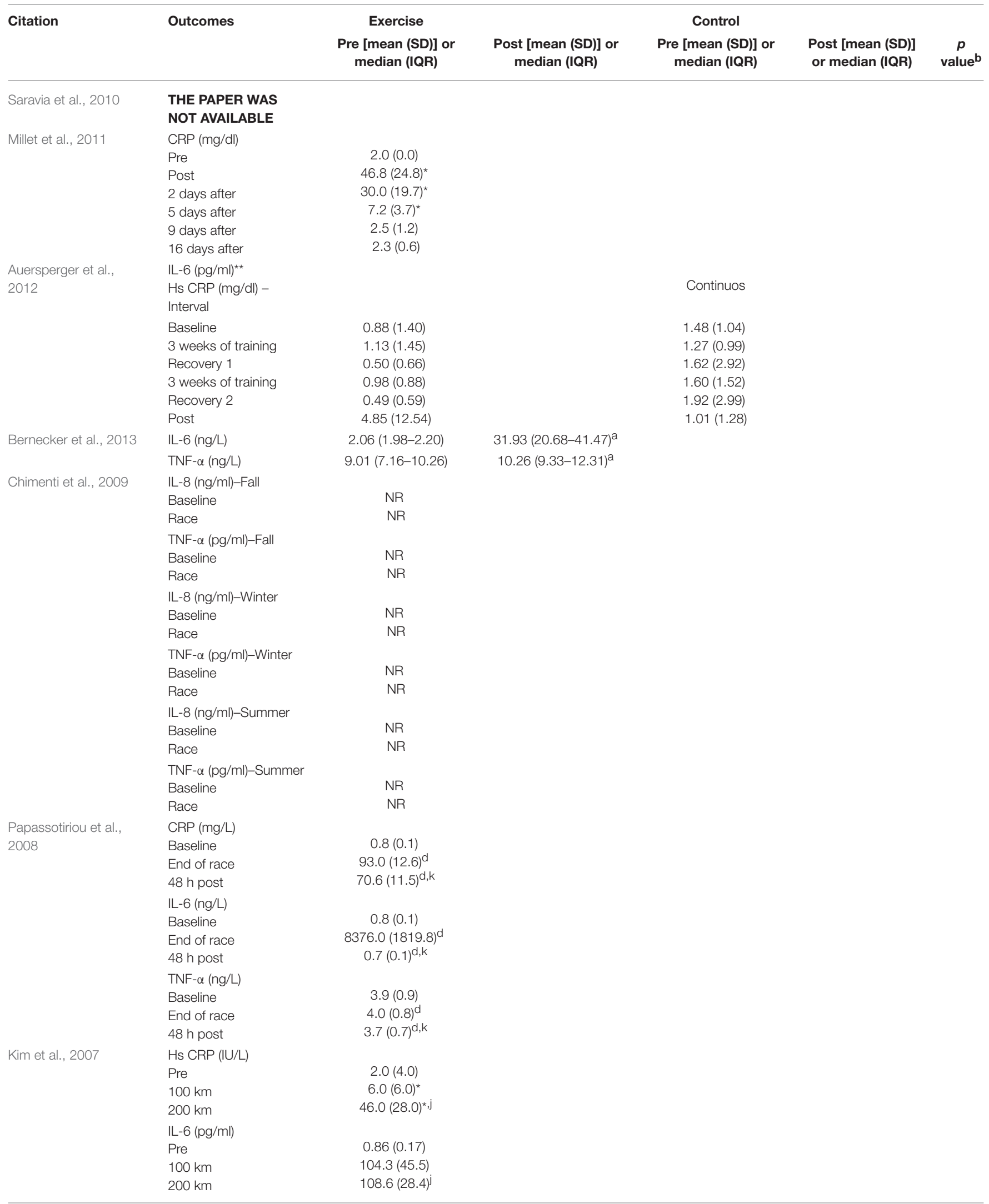


TABLE 4 | Continued

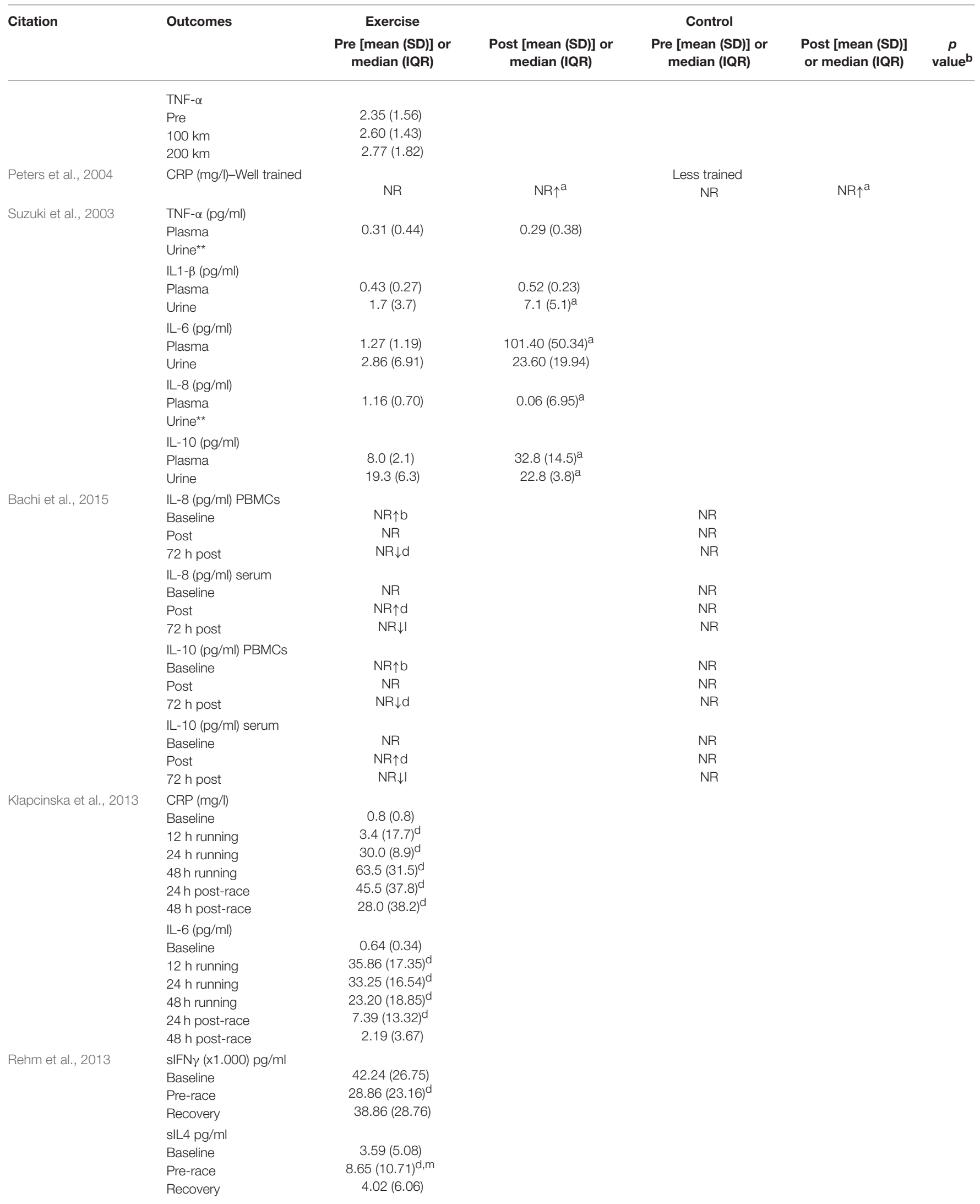


TABLE 4 | Continued

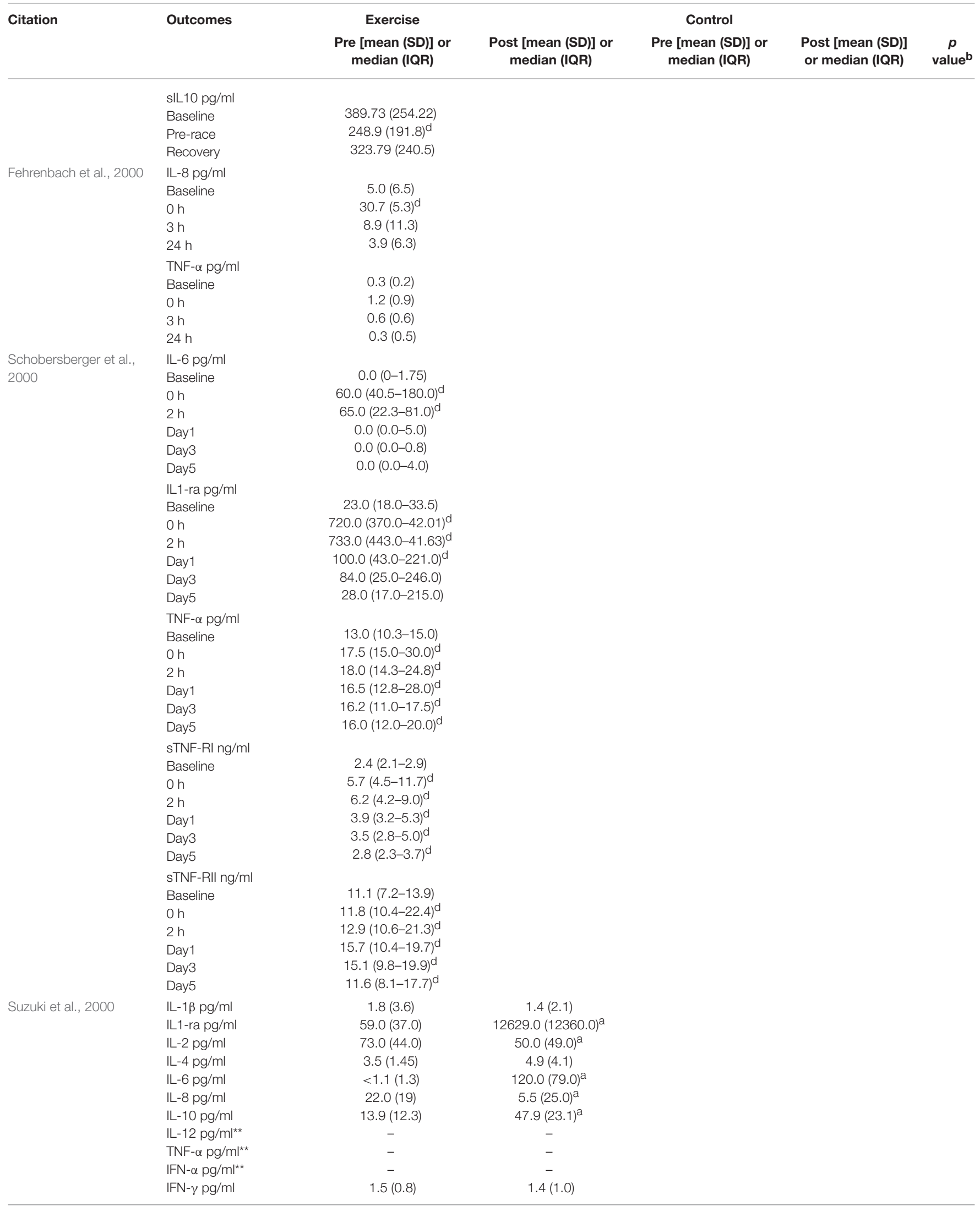


TABLE 4 | Continued

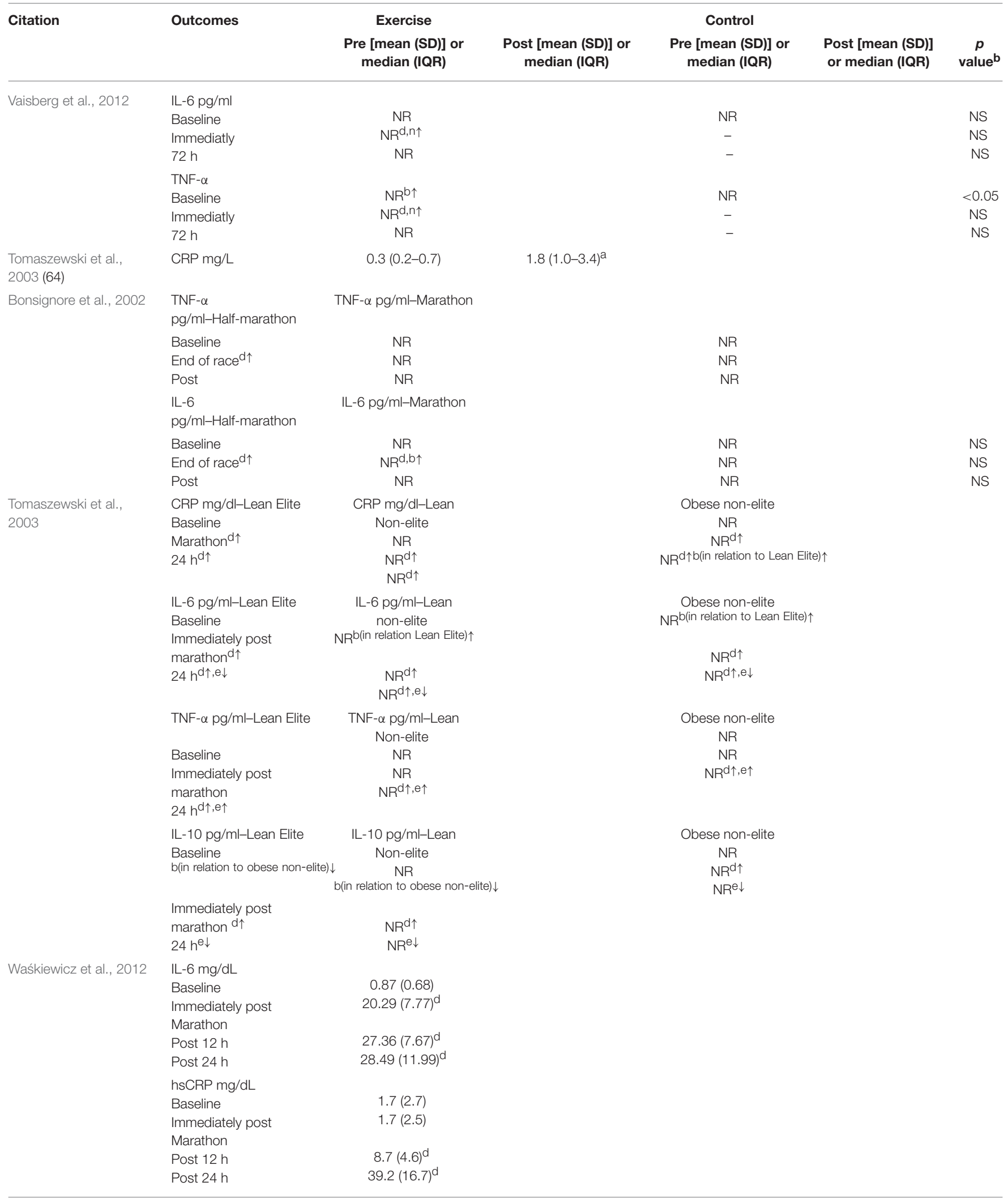


TABLE 4 | Continued

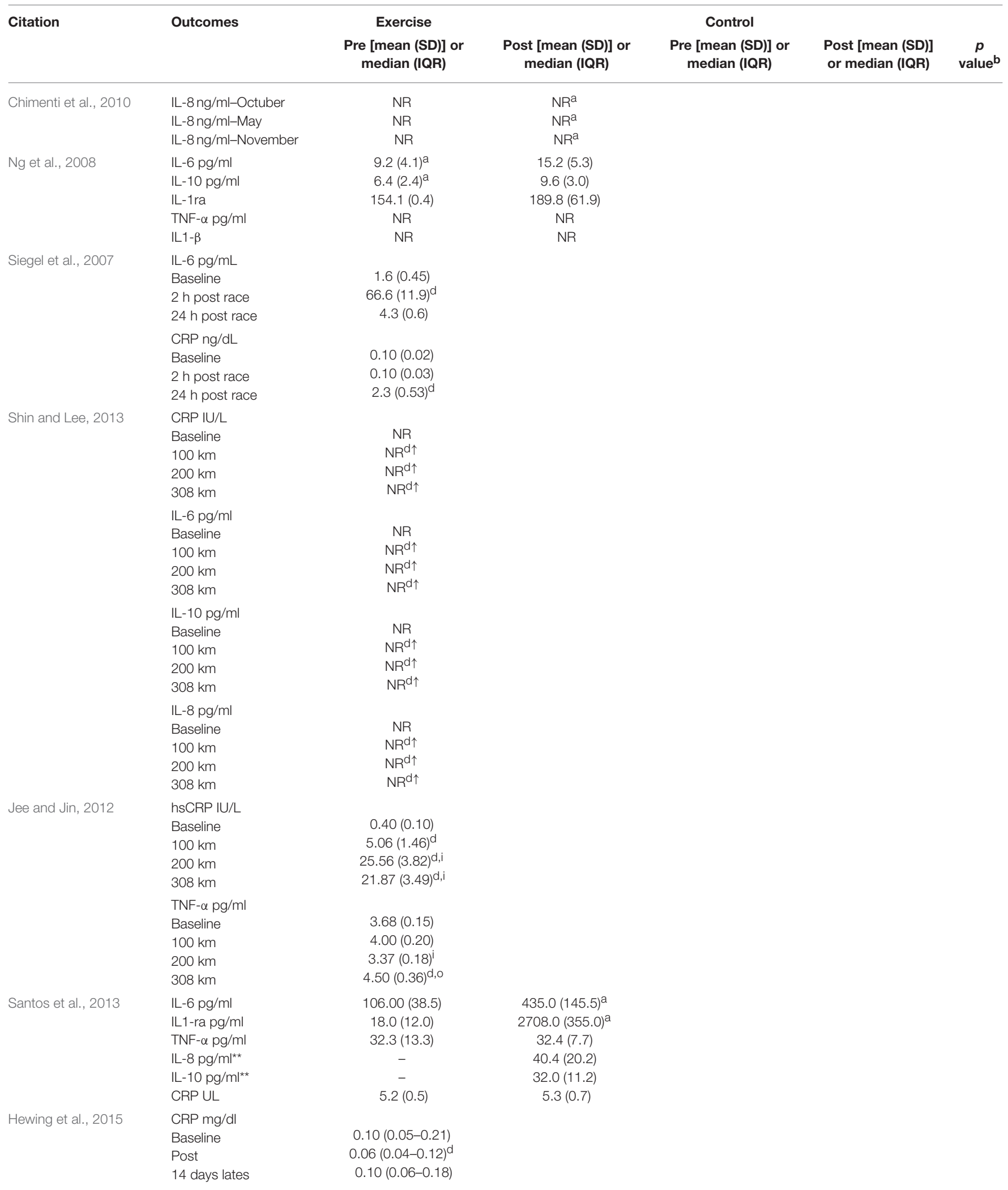


TABLE 4 | Continued

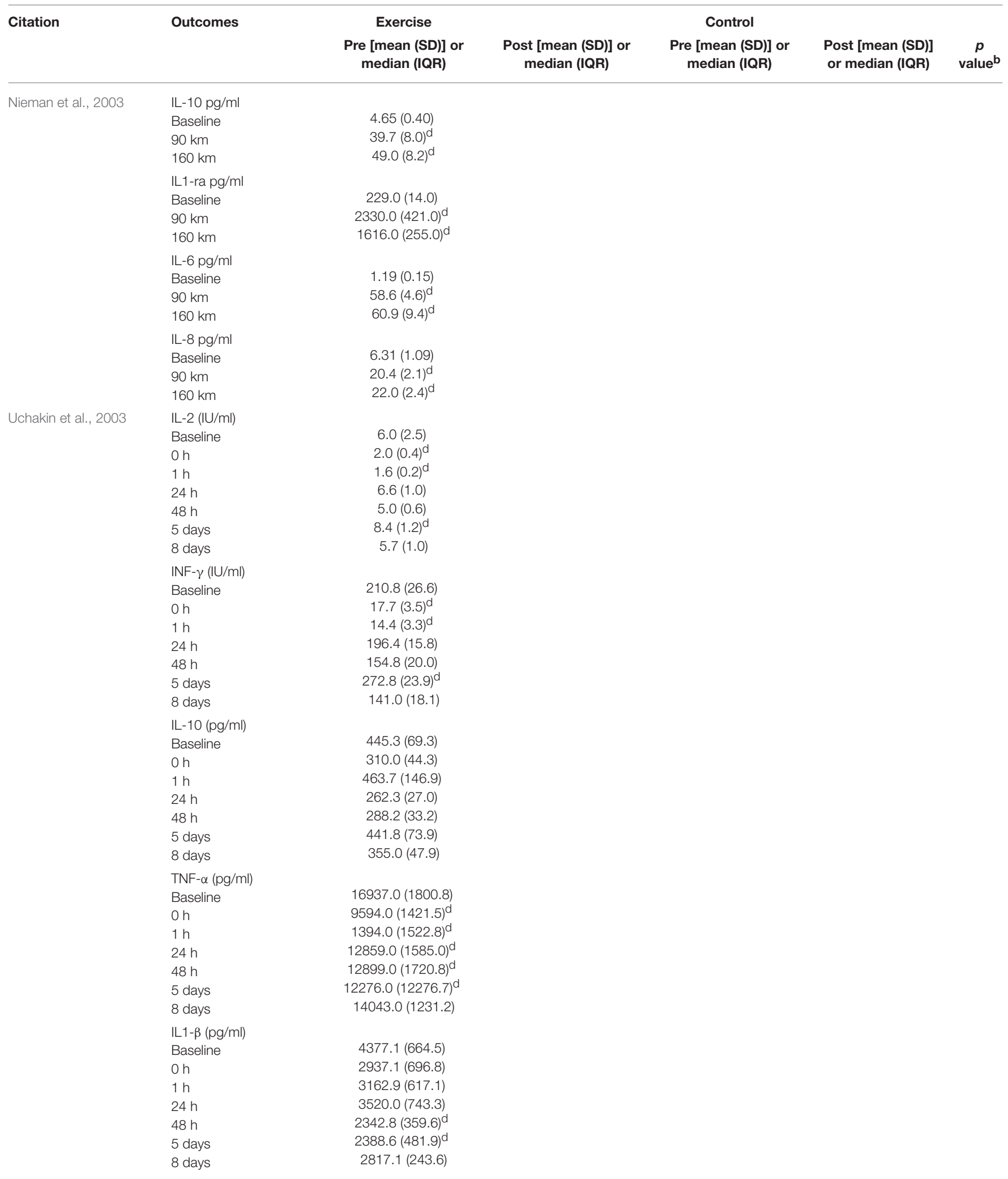


TABLE 4 | Continued

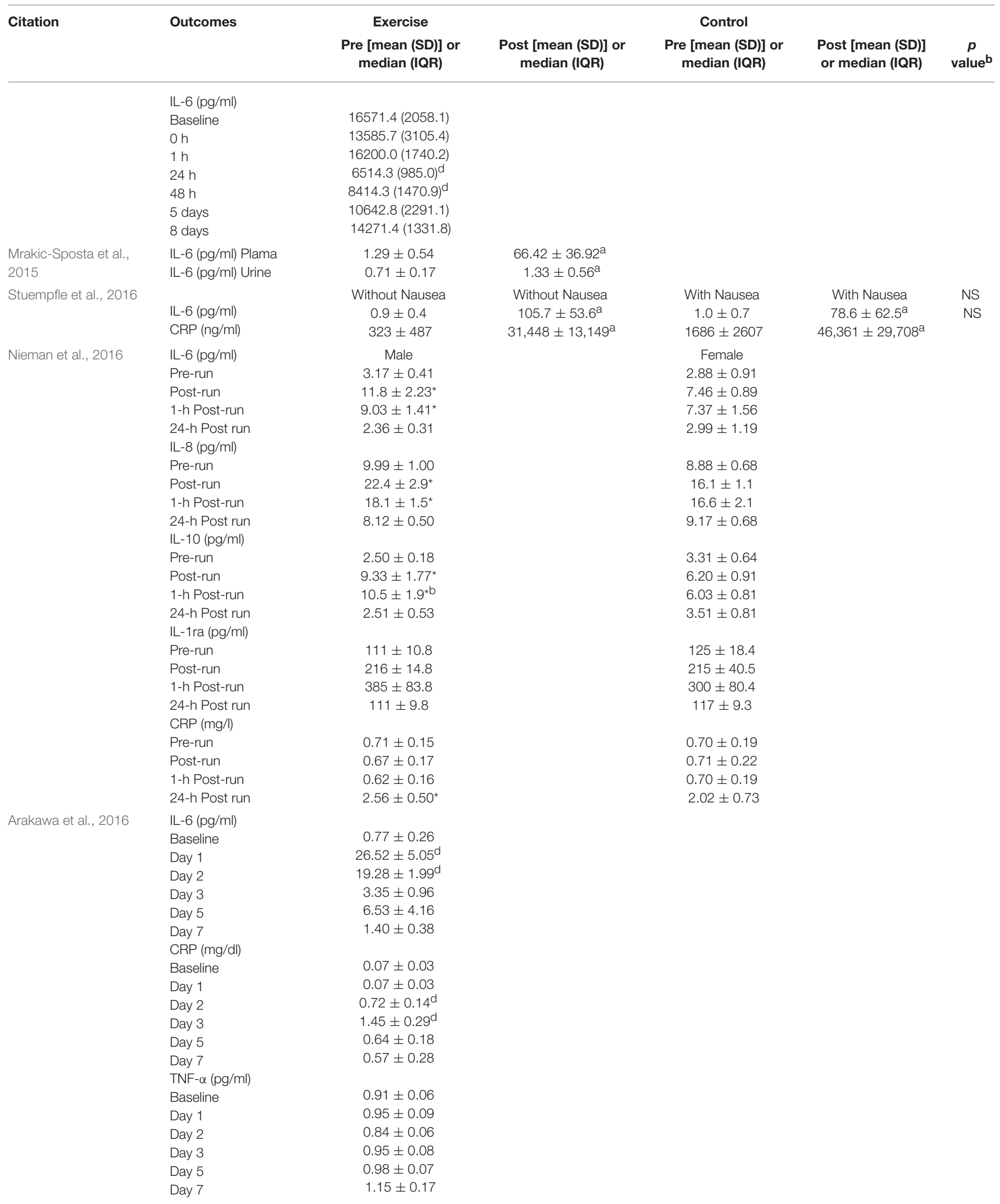


TABLE 4 | Continued

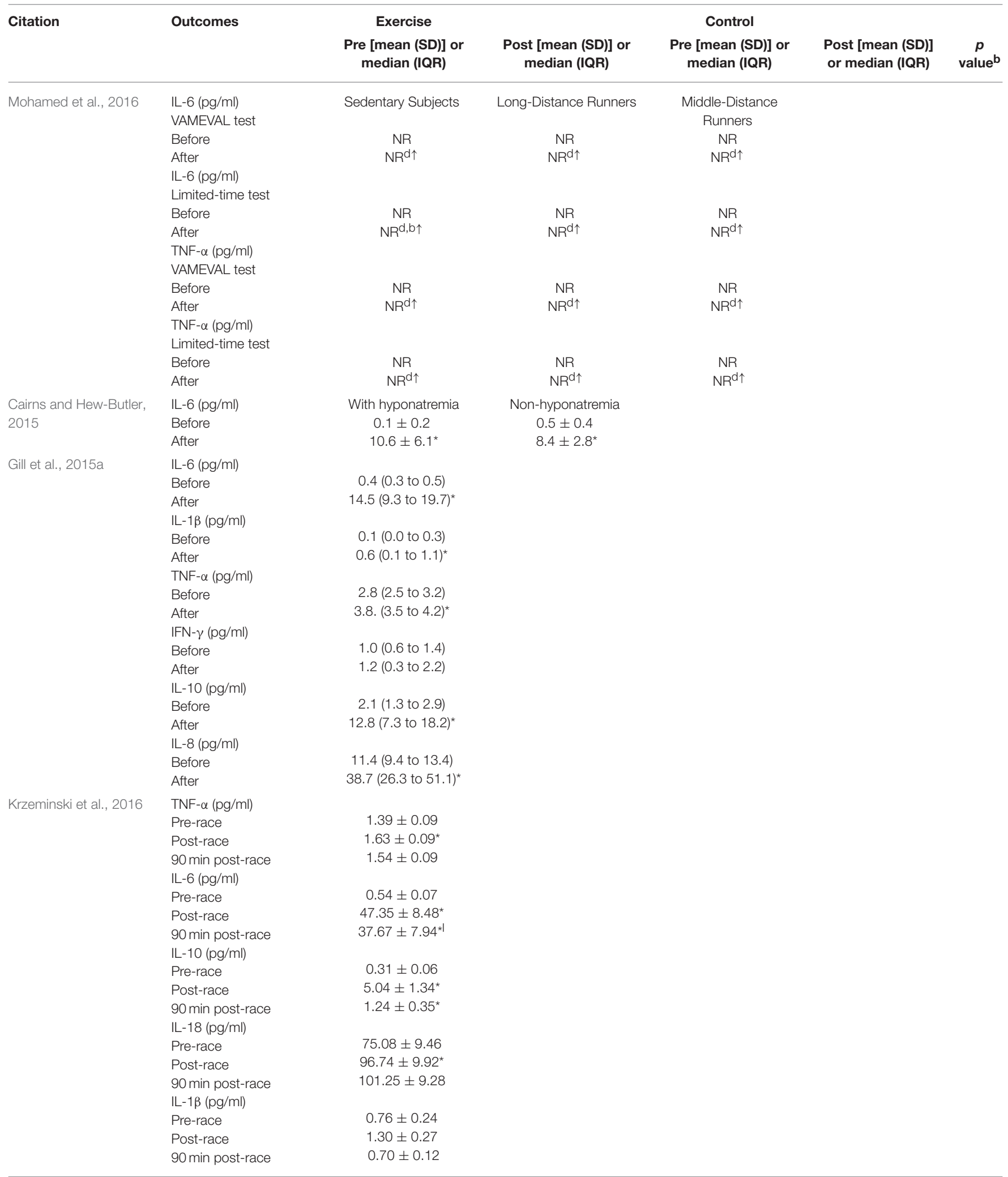


TABLE 4 | Continued

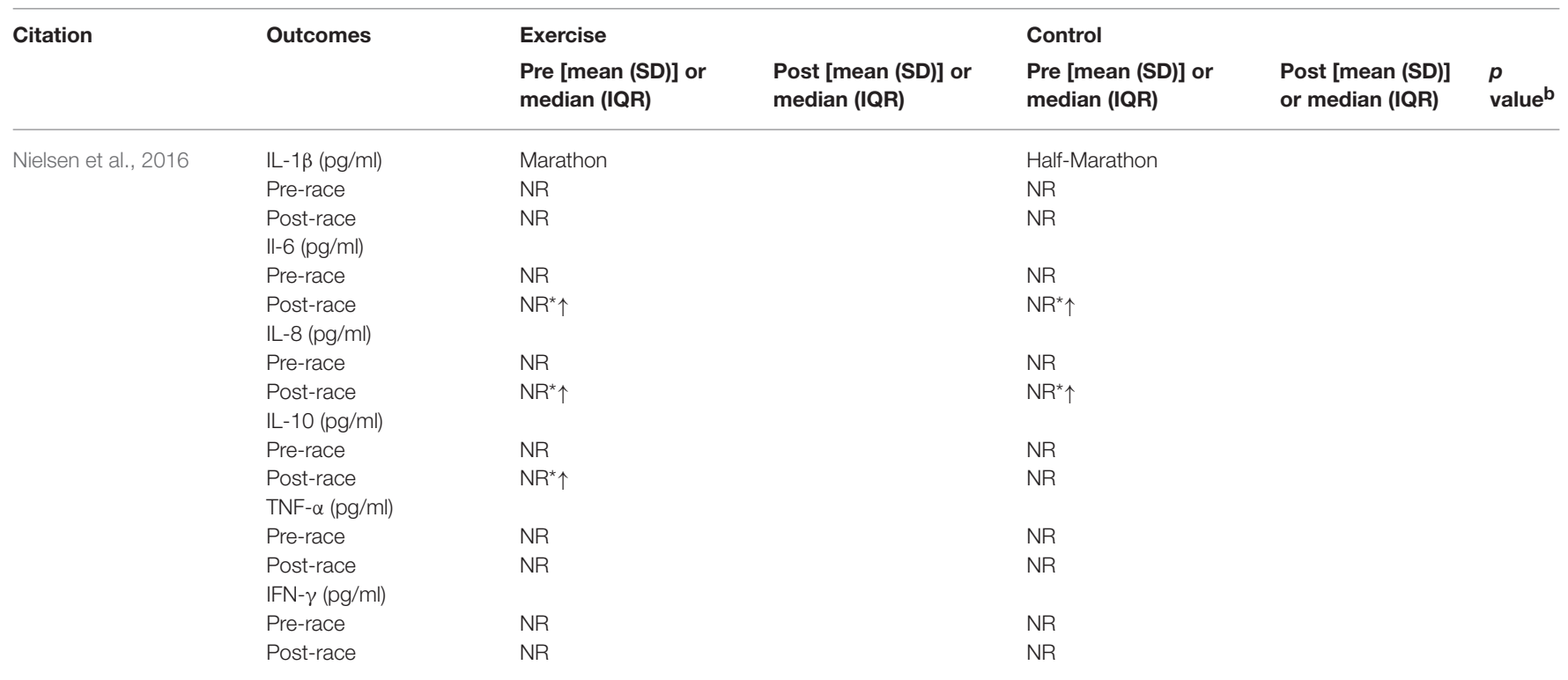

NS, not significant; -, not compared or evaluated; **, below the detectable plasma concentrations; NR, not reported; PBMCs, produced by peripheral blood mononuclear cells; IL-6, interleukin 6; CRP, C-reactive protein; IL-8, interleukin- eight; IL-2, interleukin two; IL-4, interleukin four; IL-10, interleukin tem; IL-12, interleukin 12; IFN- $\gamma$, interferon gama; TNF- $\alpha$, turmor necroses factor alpha; IL1-ra, receptor antogonist of interleukin one; IL1- $\beta$, interleukin beta; sTNF-R, soluble receptor for turmor necroses factor alpha; sIL6-R, soluble receptor antagonista for interleukin six; 0 h, immediately post-race; ${ }^{\dagger}$ Significant difference $(p<0.05)$ vs. pre-stage 1 ; ${ }^{\star}$ Significant difference $(p<0.05)$ vs. pre; ${ }^{2}$ Significant difference $(p<0.05)$ between pre and post for the same group; b Significant difference $(p<0.05)$ between groups; ${ }^{c}$ Significant difference $(p<0.05)$ vs. T0; ${ }^{d}$ Significant difference $(p<0.05)$ vs. baseline; ${ }^{e}$ Significant difference $(p<0.05)$ vs. immediately; ${ }^{f}$ Significant difference $(p<0.05)$ vs. $25 \mathrm{~km}$; ${ }^{g}$ Significant difference $(p<0.05)$ vs. $50 \mathrm{~km}$; ${ }^{h}$ Significant difference $(p<0.05)$ vs. $75 \mathrm{~km}$; 'Significant difference $(p<0.05)$ vs. post; ' significant difference $(p<0.05)$ vs. $100 \mathrm{~km}$; ${ }^{k}$ Significant difference $(p<0.05)$ vs. end of race; 'Significant difference ( $\left.p<0.05\right)$ vs. post;

m Significant difference $(p<0.05)$ vs. recovery; ${ }^{n}$ Significant difference $(p<0.05)$ vs. $72 \mathrm{~h}$; ${ }^{\circ}$ Significant difference $(p<0.05) v s .200 \mathrm{~km}$.

Boullosa et al., 2013) the training and competitive volumes of runners competing in ultra-endurance events. In addition, another new aspect that must be raised in further studies is the imbalance between training phases and recovery not reported in the studies included in this systematic review. Thus, since functional overreaching might be related to inflammation (Steinacker et al., 2004), further studies should explore these relationship in conjunction with other biological markers of overreaching.

Another important characteristic for a better characterization of runners is their fitness level. For instance, maximum oxygen consumption $\left(\mathrm{VO}_{2} \mathrm{max}\right)$, which is the gold standard for aerobic evaluation, has been reported only in 14 articles (3 studies with participants of both sexes (Nieman et al., 2003, 2016; $\mathrm{Ng}$ et al., 2008; Chimenti et al., 2009; Jee et al., 2013), and 11 studies with males (Millet et al., 2011; Jee and Jin, 2012; Waśkiewicz et al., 2012; Kłapcinska et al., 2013; Shin and Lee, 2013; Wilhelm et al., 2014; Kim et al., 2015; Krzeminski et al., 2016; Mohamed et al., 2016). The participants of these studies could be considered recreational runners when classified by their actual $\mathrm{VO}_{2} \max$ (44-51 and 35-41 mL.kg-1.min-1, for males and females, respectively) (Martin and Coe, 2007). In contrast, no study included elite runners when classified by their actual $\mathrm{VO}_{2} \max (70-85 \mathrm{~mL} . \mathrm{kg}-1 . \mathrm{min}-1$ and $61-73 \mathrm{~mL} . \mathrm{kg}-$ 1.min-1 for males and females respectively) (Martin and Coe, 2007). Moreover, runners' classification in the current review has been challenging when using the selected criteria (see Table 3 ) (Stirling and Kerr, 2006; MeSH, 2015). Thus, further studies should provide all these informations for a better characterization of runners. As we did not perceive an influence of aerobic fitness on inflammatory markers, further studies should elaborate on this relationship while controlling other runners' characteristics as training experience. Additionally, the influence of other fitness components as muscle strength capacity should be assessed in further studies for verifying the potentially protective effect for muscle damage and therefore on inflammation.

Another important limitation for generalization of the results refers to the heterogeneity of running exercises (e.g., distance, intensity) used for evaluation of acute inflammatory responses. Furthermore, ambient characteristics (e.g., altitude, temperature) and race profile (e.g., uphill and downhill running) which have been suggested to influence muscle contraction and physiological responses (Vernillo et al., 2017), have not been always reported (Millet et al., 2011; Saugy et al., 2013). These aspects should be controlled in further studies for isolating the relative effect of every specific factor on inflammation.

\section{Body Fatness and Inflammation}

Given the relationship between adipose tissue and inflammation (Pedersen and Febbraio, 2012), attention should be paid to overweight and obese runners. For instance, a higher level of CRP $24 \mathrm{~h}$ following a marathon has been observed in obese nonelite runners when compared to lean elite runners (Nickel et al., 2012). Furthermore, obese non-elite runners when compared to lean elite and lean non-elite runners demonstrated a higher level of IL- 6 and a lower level of IL-10 serum levels at baseline 
(Nickel et al., 2012). However, all groups presented an increase for serum IL-10 and TNF- $\alpha$, and a decrease for serum IL-6 levels, immediately post-marathon (Nickel et al., 2012). It must be considered that increments in IL-10 induced by exercise may be responsible for the elevation in IL1-ra which exerts an antiinflammatory action by antagonizing IL- 1 and IL- $1 \beta$ (Dinarello, 2000; Moldoveanu et al., 2001; Petersen and Pedersen, 2005; Pedersen, 2011). Nevertheless, it could be suggested that, in overweighted individuals, a higher pro-inflammatory status at baseline and post-marathon could be observed, with unknow consequences for health in the long term.

\section{Inflammation and Cardiovascular Health}

One relevant issue refers to the link between inflammation and cardiovascular health. Interestingly, the exercise-induced increase of IL- 6 after the marathon in 20 lean male runners was associated with a lower prevalence of arrhythmias during and after the marathon race (Grabs et al., 2015). When produced by muscle contraction, IL-6 stimulates the synthesis of other anti-inflammatory cytokines such as IL-1ra and IL10 , thus providing an inhibitory effect on pro-inflammatory cytokines such as IL-1 $\beta$ and TNF- $\alpha$ (Pedersen and Febbraio, 2012; Pedersen, 2013). However, CRP, a strong predictor of cardiovascular events, is an acute phase protein synthesized in the liver by the stimulation of IL-6 (Ridker et al., 2002). Chronic endurance training may decrease CRP values, especially when accompanied by a loss in fat mass, therefore promoting further reduction of risk for cardiovascular events (Fallon et al., 2001; Tomaszewski et al., 2003; Walsh et al., 2011; Grabs et al., 2015; Kim et al., 2015). Of note, CRP may be more susceptible to chronically decrease in individuals presenting higher baseline levels (Barnett et al., 2005). Therefore, caution should be taken when evaluating the anti- and pro-inflammatory effects of running in individuals with different characteristics regarding cardiovascular risk factors (e.g., body composition) (Moldoveanu et al., 2000; Petersen and Pedersen, 2005; Walsh et al., 2011).

\section{Studies' Characteristics}

Most studies included in this systematic review were acute interventions (49 studies). However acute changes in inflammatory markers might not be related with anti- and pro-inflammatory outcomes during chronic aerobic training interventions. For instance, there were divergent responses for CRP changes in chronic interventions (Mattusch et al., 2000; Auersperger et al., 2012). Thus, while Mattusch et al. (2000) observed a reduction in CRP levels, Auersperger et al. (2012) did not observe any change. Therefore, further studies must

\section{REFERENCES}

Abbasi, A., Fehrenbach, E., Hauth, M., Walter, M., Hudemann, J., Wank, V., et al. (2013). Changes in spontaneous and LPS-induced ex vivo cytokine production and mRNA expression in male and female athletes following prolonged exhaustive exercise. Exerc. Immunol. Rev. 19, 8-28. consider this important limitation, while providing training load charactersitics as volume, intensity, and frequency of training sessions. An important question to be answered refers to the minimal training load required for runners of different levels when preparing different competitive distances, while analyzing the impact of these factors on inflammatory markers. Additionally, there is a prevalence of male runners on literature therefore more studies with female runners are needed.

\section{CONCLUSION}

In summary, our results revealed that acute and chronic endurance running may affect anti- and pro-inflammatory markes but methodological differences between studies do not allow comparisons or generalization of the results. Only two studies were chronic interventions. There are no studies with elite athletes. Thus, RCTs are urgently needed to identify the appropriate dose of endurance running (volume, intensity, and frequency) required to elicit improvements in inflammatory markers in runners of different levels and training background. External (e.g., ambient characteristics, race profile) and internal factors (e.g., fitness level, training experience) to runners should be considered in further studies for a better understanding of the relationship between running and the mediators of inflammation. The information provided in this systematic review would help practitioners for better designing further studies while providing reference values for a better understanding of inflammatory responses after different running events.

\section{AUTHOR CONTRIBUTIONS}

Conception and design: EB, CC, ON, JP, and DB. Search: EB, DN, and FS. Eligibility and outcome measures: EB and DN. Quality assessment: DN and JP. Writing of the manuscript: EB, DN, JP, $\mathrm{ON}, \mathrm{CC}$, and DB. Revision and approval of the final manuscript version and interpretation of the results: $\mathrm{EB}, \mathrm{DN}, \mathrm{JP}, \mathrm{ON}, \mathrm{CC}, \mathrm{FS}$, and DB.

\section{FUNDING}

DN enjoys a PROSUP grant from CAPES. DB and JP enjoy a productivity research grant from $\mathrm{CNPq}$.

\section{ACKNOWLEDGMENTS}

The first and second authors would like to thank the support of their families (Rita and Nicolas). 
inflammatory parameters, and iron status in female runners. Int. J. Sport Nutr. Exerc. Metab. 1, 55-63. doi: 10.1123/ijsnem.22.1.55

Bachi, A. L., Rios, F. J., Vaisberg, P. H., Martins, M., de Sá, M. C., Victorino, A. B., et al. (2015). Neuro-immuno-endocrine modulation in marathon runners. Neuroimmunomodulation 22, 196-202. doi: 10.1159/000363061

Barnett, A. G., van der Pols, J. C., and Dobson, A. J. (2005). Regression to the mean: what it is and how to deal with it. Int. J. Epidemiol. 34, 215-220. doi: $10.1093 / \mathrm{ije} / \mathrm{dyh} 299$

Bernecker, C., Scherr, J., Schinner, S., Braun, S., Scherbaum, W. A., and Halle, M. (2013). Evidence for an exercise induced increase of TNF-alpha and IL-6 in marathon runners. Scand. J. Med. Sci. Sports 23, 207-214. doi: 10.1111/j.1600-0838.2011.01372.x

Bonsignore, M. R., Morici, G., Santoro, A., Pagano, M., Cascio, L., Bonanno, A., et al. (2002). Circulating hematopoietic progenitor cells in runners. J. Appl. Physiol. 93, 1691-1697. doi: 10.1152/japplphysiol.00376.2002

Boullosa, D. A., Abreu, L., Varela-Sanz, A., and Mujika, I. (2013). Do olympic athletes train as in the Paleolithic era? Sports Med. 43, 909-917. doi: 10.1007/s40279-013-0086-1

Bramble, D. M., and Lieberman, D. E. (2004). Endurance running and the evolution of Homo. Nature 432, 345-352. doi: 10.1038/nature03052

Cairns, R. S., and Hew-Butler, T. (2015). Incidence of exercise-associated hyponatremia and its association with nonosmotic stimuli of arginine vasopressin in the GNW100s ultra-endurance marathon. Clin. J. Sport Med. 25, 347-354. doi: 10.1097/JSM.0000000000000144

Chiampas, G. T., and Goyal, A. V. (2015). Innovative operations measures and nutritional support for mass endurance events. Sports Med. 45, 61-69. doi: 10.1007/s40279-015-0396-6

Chimenti, L., Morici, G., Paterno, A., Bonanno, A., Vultaggio, M., Bellia, V., et al. (2009). Environmental conditions, air pollutants, and airway cells in runners: a longitudinal field study. J. Sports Sci. 27, 925-935. doi: $10.1080 / 02640410902946493$

Chimenti, L., Morici, G., Paternò, A., Santagata, R., Bonanno, A., Profita, M., et al. (2010). Bronchial epithelial damage after a half-marathon in nonasthmatic amateur runners. Am. J. Physiol. Lung Cell. Mol. Physiol. 298, L857-L862. doi: 10.1152/ajplung.00053.2010

Dinarello, C. A. (2000). The role of the interleukin-1-receptor antagonist in blocking inflammation mediated by interleukin-1. N. Engl. J. Med. 343, 732-734. doi: 10.1056/NEJM200009073431011

Downs, S. H., and Black, N. (1998). The feasibility of creating a checklist for the assessment of the methodological quality both of randomised and nonrandomised studies of health care interventions. J. Epidemiol. Commun. Health 52, 377-384. doi: 10.1136/jech.52.6.377

Fallon, K. E., Fallon, S. K., and Boston, T. (2001). The acute phase response and exercise: court and field sports. Br. J. Sports Med. 35, 170-173. doi: $10.1136 /$ bjsm.35.3.170

Febbraio, M. A., and Pedersen, B. K. (2005). Contraction-induced myokine production and release: is skeletal muscle an endocrine organ? Exerc. Sport Sci. Rev. 33, 114-119. doi: 10.1097/00003677-200507000-00003

Fehrenbach, E., Niess, A. M., Schlotz, E., Passek, F., Dickhuth, H. H., and Northoff, H. (2000). Transcriptional and translational regulation of heat shock proteins in leukocytes of endurance runners. J. Appl. Physiol. 89, 704-710.

Gill, S. K., Hankey, J., Wright, A., Marczak, S., Hemming, K., Allerton, D. M., et al. (2015a). The impact of a 24-h ultra-marathon on circulatory endotoxin and cytokine profile. Int. J. Sports Med. 36, 688-695. doi: 10.1055/s-0034-1398535

Gill, S. K., Teixeira, A., Rama, L., Prestes, J., Rosado, F., Hankey, J., et al. (2015b). Circulatory endotoxin concentration and cytokine profile in response to exertional-heat stress during a multi-stage ultra-marathon competition. Exerc. Immunol. Rev. 21, 114-128.

Gleeson, M. (2007). Immune function in sport and exercise. J. Appl. Physiol. 103, 693-699. doi: 10.1152/japplphysiol.00008.2007

Grabs, V., Peres, T., Zelger, O., Haller, B., Pressler, A., Braun, S., et al. (2015). Decreased prevalence of cardiac arrhythmias during and after vigorous and prolonged exercise in healthy male marathon runners. Am. Heart J. 170, 149-155. doi: 10.1016/j.ahj.2015.04.001

Hewing, B., Schattke, S., Spethmann, S., Sanad, W., Schroeckh, S., Schimke, I., et al. (2015). Cardiac and renal function in a large cohort of amateur marathon runners. Cardiovasc. Ultrasound. 13:13. doi: 10.1186/s12947-015-0007-6
Hubble, K. M., Fatovich, D. M., Grasko, J. M., and Vasikaran, S. D. (2009). Cardiac troponin increases among marathon runners in the Perth Marathon: the Troponin in Marathons (TRIM) study. Med. J. Aust.. 190, 91-93.

Jarvinen, T. A., Jarvinen, M., and Kalimo, H. (2013). Regeneration of injured skeletal muscle after the injury. Muscles Ligaments Tendons J. 3, 337-345.

Jee, H., and Jin, Y. (2012). Effects of prolonged endurance exercise on vascular endothelial and inflammation markers. J. Sports Sci. Med. 11, 719-726.

Jee, H., Park, J., Oh, J.-G., Lee, Y.-H., Shin, K.-A., and Kim, Y.-J. (2013). Effect of a prolonged endurance marathon on vascular endothelial and inflammation markers in runners with exercise-induced hypertension. Am. J. Pbys. Med. Rehabil. 92, 513-522. doi: 10.1097/PHM.0b013e31829232db

Karstoft, K., Solomon, T. P., Laye, M. J., and Pedersen, B. K. (2013). Daily marathon running for a week-the biochemical and body compositional effects of participation. J. Strength Cond. Res. 27, 2927-2933. doi: 10.1519/JSC.0b013e318289e39d

Kasprowicz, K., Ziemann, E., Ratkowski, W., Laskowski, R., Kaczor, J. J., Dadci, R., et al. (2013). Running a 100-km ultra-marathon induces an inflammatory response but does not raise the level of the plasma iron-regulatory protein hepcidin. J. Sports Med. Phys. Fitness. 53, 533-537.

Kim, H. J., Lee, Y. H., and Kim, C. K. (2007). Biomarkers of muscle and cartilage damage and inflammation during a $200 \mathrm{~km}$ run. Eur. J. Appl. Physiol. 99, 443-447. doi: 10.1007/s00421-006-0362-y

Kim, Y. J., Ahn, J. K., Shin, K. A., Kim, C. H., Lee, Y. H., and Park, K. M. (2015). Correlation of cardiac markers and biomarkers with blood pressure of middleaged marathon runners. J. Clin. Hypertens. 17, 868-873. doi: 10.1111/jch.12591

Kłapcinska, B., Waskiewicz, Z., Chrapusta, S. J., Sadowska-Krepa, E., Czuba, M., and Langfort, J. (2013). Metabolic responses to a 48-h ultra-marathon run in middle-aged male amateur runners. Eur. J. Appl. Physiol. 113, 2781-2793. doi: 10.1007/s00421-013-2714-8

Krzeminski, K., Buraczewska, M., Miśkiewicz, Z., Dabrowski, J., Steczkowska, M., Kozacz, A., et al. (2016). Effect of ultra-endurance exercise on left ventricular performance and plasma cytokines in healthy trained men. Biol. Sport. 33, 63-69. doi: 10.5604/20831862.1189767

Liberati, A., Altman, D. G., Tetzlaff, J., Mulrow, C., Gøtzsche, P. C., Ioannidis, J. P., et al. (2009). The PRISMA statement for reporting systematic reviews and meta-analyses of studies that evaluate healthcare interventions: explanation and elaboration. Br. Med. J. 339:b2700. doi: 10.1136/bmj.b2700

Martin, D. E., and Coe, P. N. (2007). Entrenamiento para Corredores de Fondo y Medio Fondo. Paidotribo.

Mattusch, F., Dufaux, B., Heine, O., Mertens, I., and Rost, R. (2000). Reduction of the plasma concentration of C-reactive protein following nine months of endurance training. Int. J. Sports Med. 21, 21-24. doi: 10.1055/s-2000-8852

Meeusen, R., Duclos, M., Foster, C., Fry, A., Gleeson, M., Nieman, D., et al. (2013). Prevention, diagnosis, and treatment of the overtraining syndrome: joint consensus statement of the European College of Sport Science and the American College of Sports Medicine. Med. Sci. Sports Exerc. 45, 186-205. doi: 10.1249/MSS.0b013e318279a10a

MeSH (2015). MeSH (Medical Subject Headings) is the NLM Controlled Vocabulary Thesaurus Used for Indexing Articles for PubMed. Available online at: http:// www.ncbi.nlm.nih.gov/mesh/ (Acessed November 1, 2015).

Millet, G. Y., Tomazin, K., Verges, S., Vincent, C., Bonnefoy, R., Boisson, R. C., et al. (2011). Neuromuscular consequences of an extreme mountain ultramarathon. PLoS ONE 6:e17059. doi: 10.1371/journal.pone.0017059

Mohamed, S., Lamya, N., and Hamda, M. (2016). Effect of maximal versus supra-maximal exhausting race on lipid peroxidation, antioxidant activity and muscle-damage biomarkers in long-distance and middle-distance runners. Asian J. Sports Med. 7:e27902. doi: 10.5812/asjsm.27902

Mohlenkamp, S., Bose, D., Mahabadi, A. A., Heusch, G., and Erbel, R. (2007). On the paradox of exercise: coronary atherosclerosis in an apparently healthy marathon runner. Nat. Clin. Pract. Cardiovasc. Med. 4, 396-401. doi: 10.1038/ncpcardio0926

Moldoveanu, A. I., Shephard, R. J., and Shek, P. N. (2000). Exercise elevates plasma levels but not gene expression of IL-1beta, IL-6, and TNF-alpha in blood mononuclear cells. J. Appl. Physiol. 4, 1499-1504.

Moldoveanu, A. I., Shephard, R. J., and Shek, P. N. (2001). The cytokine response to physical activity and training. Sports Med. 31, 115-144. doi: 10.2165/00007256-200131020-00004 
Mrakic-Sposta, S., Gussoni, M., Moretti, S., Pratali, L., Giardini, G., Tacchini, P., et al. (2015). Effects of mountain ultra-marathon running on ros production and oxidative damage by micro-invasive analytic techniques. PLoS ONE 10:e0141780. doi: 10.1371/journal.pone.0141780

Neidhart, M., Müller-Ladner, U., Frey, W., Bosserhoff, A. K., Colombani, P. C., Frey-Rindova, P., et al. (2000). Increased serum levels of noncollagenous matrix proteins (cartilage oligomeric matrix protein and melanoma inhibitory activity) in marathon runners. Osteoarthr. Cartil. 8, 222-229. doi: 10.1053/joca.1999.0293

Ng, Q. Y., Lee, K. W., Byrne, C., Ho, T. F., and Lim, C. L. (2008). Plasma endotoxin and immune responses during a $21-\mathrm{km}$ road race under a warm and humid environment. Ann. Acad. Med. Singap. 37, 307-314.

Nickel, T., Emslander, I., Sisic, Z., David, R., Schmaderer, C., Marx, N., et al. (2012). Modulation of dendritic cells and toll-like receptors by marathon running. Eur. J. Appl. Physiol. 112, 1699-1708. doi: 10.1007/s00421-011-2140-8

Nielsen, H. G., Øktedalen, O., Opstad, P. K., and Lyberg, T. (2016). Plasma cytokine profiles in long-term strenuous exercise. J. Sports Med. 2016:7186137. doi: 10.1155/2016/7186137

Nieman, D. C. (2009). Immune function responses to ultramarathon race competition. Med. Sport. 13, 189-196. doi: 10.2478/v10036-009-0031-4

Nieman, D. C., Dumke, C. I., Henson, D. A., McAnulty, S. R., McAnulty, L. S., Lind, R. H., et al. (2003). Immune and oxidative changes during and following the Western States Endurance Run. Int. J. Sports Med. 24, 541-547. doi: $10.1055 /$ s-2003-42018

Nieman, D. C., Dumke, C. L., Henson, D. A., McAnulty, S. R., Gross, S. J., and Lind, R. H. (2005). Muscle damage is linked to cytokine changes following a 160-km race. Brain Behav. Immun. 19, 398-403. doi: 10.1016/j.bbi.2005.03.008

Nieman, D. C., Johanssen, L. M., and Lee, J. W. (1989). Infectious episodes in runners before and after a roadrace. J. Sports Med. Phys. Fitness 29, 289-296.

Nieman, D. C., Johanssen, L. M., Lee, J. W., and Arabatzis, K. (1990). Infectious episodes in runners before and after the Los Angeles Marathon. J. Sports Med. Phys. Fitness 30, 316-328.

Nieman, D. C., Meaney, M. P., John, C. S., Knagge, K. J., and Chen, H. (2016). 9- and 13-Hydroxy-octadecadienoic acids (9+13 HODE) are inversely related to granulocyte colony stimulating factor and IL-6 in runners after $2 \mathrm{~h}$ running. Brain Behav. Immun. 56, 246-252. doi: 10.1016/j.bbi.2016.03.020

Niess, A. M., Sommer, M., Schlotz, E., Northoff, H., Dickhuth, H. H., and Fehrenbach, E. (2000). Expression of the inducible nitric oxide synthase (iNOS) in human leukocytes: responses to running exercise. Med. Sci. Sports Exerc. 32, 220-1225. doi: 10.1097/00005768-200007000-00006

O'Brien, M. (2012). The reciprocal relationship between inflammation and coagulation. Top. Companion Anim. Med. 27, 46-52. doi: 10.1053/j.tcam.2012. 06.003

O'Keefe, J. H., and Lavie, C. J. (2013). Run for your life... at a comfortable speed and not too far. Heart 99, 516-519. doi: 10.1136/heartjnl-2012-302886

O'Keefe, J. H., Vogel, R., Lavie, C. J., and Cordain, L. (2010). Achieving huntergatherer fitness in the 21(st) century: back to the future. Am. J. Med. 123, 1082-1086. doi: 10.1016/j.amjmed.2010.04.026

Papassotiriou, I., Alexiou, V. G., Tsironi, M., Skenderi, K., Spanos, A., and Falagas, M. E. (2008). Severe aseptic inflammation caused by long distance running (246 km) does not increase procalcitonin. Eur. J. Clin. Invest. 38, 276-279. doi: 10.1111/j.1365-2362.2008.01935.x

Pedersen, B. K. (2011). Muscles and their myokines. J. Exp. Biol. 214, 337-346. doi: $10.1242 /$ jeb. 048074

Pedersen, B. K. (2013). Muscle as a secretory organ. Compr. Physiol. 3, 1337-1362. doi: $10.1002 /$ cphy.c120033

Pedersen, B. K., and Febbraio, M. A. (2012). Muscles, exercise and obesity: skeletal muscle as a secretory organ. Nat. Rev. Endocrinol. 8, 457-465. doi: $10.1038 /$ nrendo.2012.49

Peters, E. M., and Bateman, E. D. (1983). Ultramarathon running and upper respiratory tract infections. An epidemiological survey. S. Afr. Med. J. 64, 582-584.

Peters, E. M., Robson, P. J., Kleinveldt, N. C., Naicker, V. L., and Jogessar, V. D. (2004). Hematological recovery in male ultramarathon runners: the effect of variations in training load and running time. J. Sports Med. Phys. Fitness 44, 315-321.

Petersen, A. M., and Pedersen, B. K. (2005). The anti-inflammatory effect of exercise. J. Appl. Physiol. 98, 154-1162. doi: 10.1152/japplphysiol.00164.2004
Rehm, K. E., Elci, O. U., Hahn, K., and Marshall, G. D. Jr. (2013). The impact of self-reported psychological stress levels on changes to peripheral blood immune biomarkers in recreational marathon runners during training and recovery. Neuroimmunomodulation 20, 64-176. doi: 10.1159/000346795

Reihmane, D., Jurka, A., Tretjakovs, P., and Dela, F. (2013). Increase in IL-6, TNF-alpha, and MMP-9, but not sICAM-1, concentrations depends on exercise duration. Eur. J. Appl. Physiol. 113, 851-858. doi: 10.1007/s00421-012-2491-9

Ridker, P. M., Rifai, N., Rose, L., Buring, J. E., and Cook, N. R. (2002). Comparison of C-reactive protein and low-density lipoprotein cholesterol levels in the prediction of first cardiovascular events. N. Engl. J. Med. 347, 1557-1565. doi: 10.1056/NEJMoa021993

Sampson, M., McGowan, J., Cogo, E., Grimshaw, J., Moher, D., and Lefebvre, C. (2009). An evidence-based practice guideline for the peer review of electronic search strategies. J. Clin. Epidemiol. 62, 944-952. doi: 10.1016/j.jclinepi.2008.10.012

Sampson, M., McGowan, J., Tetzlaff, J., Cogo, E., and Moher, D. (2008). No consensus exists on search reporting methods for systematic reviews. J. Clin. Epidemiol. 61, 748-754. doi: 10.1016/j.jclinepi.2007.10.009

Santos, R. V., Tufik, S., and De Mello, M. T. (2007). Exercise, sleep and cytokines: is there a relation? Sleep Med. Rev. 11, 231-239. doi: 10.1016/j.smrv.2007.03.003

Santos, V. C., Levada-Pires, A. C., Alves, S. R., Pithon-Curi, T. C., Curi, R., and Cury-Boaventura, M. F. (2013). Changes in lymphocyte and neutrophil function induced by a marathon race. Cell Biochem. Funct. 31, 237-243. doi: 10.1002/cbf.2877

Saravia, S. G., Knebel, F., Schroeckh, S., Ziebig, R., Lun, A., Weimann, A., et al. (2010). Cardiac troponin T release and inflammation demonstrated in marathon runners. Clin. Lab. 56, 51-58.

Saugy, J., Place, N., Millet, G. Y., Degache, F., Schena, F., and Millet, G. P. (2013). Alterations of neuromuscular function after the world's most challenging mountain ultra-marathon. PLOS ONE 8:e65596. doi: 10.1371/ journal.pone.0065596

Schobersberger, W., Hobisch-Hagen, P., Fries, D., Wiedermann, F., RiederScharinger, J., Villiger, B., et al. (2000). Increase in immune activation, vascular endothelial growth factor and erythropoietin after an ultramarathon run at moderate altitude. Immunobiology 201, 611-620. doi: 10.1016/S01712985(00)80078-9

Scott, J. P., Sale, C., Greeves, J. P., Casey, A., Dutton, J., and Fraser, W. D. (2011). Effect of exercise intensity on the cytokine response to an acute bout of running. Med. Sci. Sports Exerc. 43, 2297-2306. doi: 10.1249/MSS.0b013e3182 $2113 \mathrm{a} 9$

Shin, Y. O., and Lee, J. B. (2013). Leukocyte chemotactic cytokine and leukocyte subset responses during ultra-marathon running. Cytokine 61, 364-369. doi: 10.1016/j.cyto.2012.11.019

Siegel, A. J., Verbalis, J. G., Clement, S., Mendelson, J. H., Mello, N. K., Adner, M., et al. (2007). Hyponatremia in marathon runners due to inappropriate arginine vasopressin secretion. Am. J. Med. 120, 461.e11-461.e17. doi: 10.1016/j.amjmed.2006.10.027

Smith, L. L. (2004). Tissue trauma: the underlying cause of overtraining syndrome? J. Strength Cond. Res. 18, 185-193. doi: 10.1519/00124278-20040200000028

Steinacker, J. M., Lormes, W., Reissnecker, S., and Liu, Y. (2004). New aspects of the hormone and cytokine response to training. Eur. J. Appl. Physiol. 91, 382-391. doi: 10.1007/s00421-003-0960-x

Stirling, A. E., and Kerr, G. A. (2006). Perfectionism and mood states among recreational and elite athletes. J. Sport Psychol. 8, 13-27.

Stuempfle, K. J., Valentino, T., Hew-Butler, T., Hecht, F. M., and Hoffman, M. D. (2016). Nausea is associated with endotoxemia during a 161-km ultramarathon. J. Sports Sci. 34, 1662-1668. doi: 10.1080/02640414.2015.1130238

Suzuki, K., Nakaji, S., Yamada, M., Liu, Q., Kurakake, S., Okamura, N., et al. (2003). Impact of a competitive marathon race on systemic cytokine and neutrophil responses. Med. Sci. Sports Exerc. 35, 348-355. doi: 10.1249/01.MSS.0000048861.57899.04

Suzuki, K., Yamada, M., Kurakake, S., Okamura, N., Yamaya, K., Liu, Q., et al. (2000). Circulating cytokines and hormones with immunosuppressive but neutrophil-priming potentials rise after endurance exercise in humans. Eur. J. Appl. Physiol. 81, 281-287. doi: 10.1007/s004210050044

Taylor, B. A., Zaleski, A. L., Capizzi, J. A., Ballard, K. D., Troyanos, C., Baggish, A. L., et al. (2014). Influence of chronic exercise on carotid atherosclerosis 
in marathon runners. Br. Med. J. Open 4:e004498. doi: 10.1136/bmjopen2013-004498

Tomaszewski, M., Charchar, F. J., Przybycin, M., Crawford, L., Wallace, A. M., Gosek, K., et al. (2003). Strikingly low circulating CRP concentrations in ultramarathon runners independent of markers of adiposity: how low can you go? Arterioscler. Thromb. Vasc. Biol. 23, 1640-1644. doi: 10.1161/01.ATV.0000087036.75849.0B

Uchakin, P. N., Gotovtseva, E. P., and Stray-Gundersen, J. (2003). Immune and neurodocrine alterations in marathon runners. J. Appl. Res. 3, 483-494.

Vaisberg, M., Bachi, A. L., Latrilha, C., Dioguardi, G. S., Bydlowski, S. P., and Maranhao, R. C. (2012). Lipid transfer to HDL is higher in marathon runners than in sedentary subjects, but is acutely inhibited during the run. Lipids 47, 679-686. doi: 10.1007/s11745-012-3685-y

Vaisberg, M., Suguri, V. M., Gregorio, L. C., Lopes, J. D., and Bachi, A. L. (2013). Cytokine kinetics in nasal mucosa and sera: new insights in understanding upper-airway disease of marathon runners. Exerc. Immunol. Rev. 19, 49-59.

Vernillo, G., Giandolini, M., Edwards, W. B., Morin, J. B., Samozino, P., Horvais, N., et al. (2017). "Biomechanics and physiology of uphill and downhill running." Sports Med. 47, 615-629. doi: 10.1007/s40279-0160605-y

Videbaek, S., Bueno, A. M., Nielsen, R. O., and Rasmussen, S. (2015). Incidence of running-related injuries per $1000 \mathrm{~h}$ of running in different types of runners: a systematic review and meta-analysis. Sports Med. 45, 1017-1026. doi: $10.1007 /$ s40279-015-0333-8
Walsh, N. P., Gleeson, M., Shephard, R. J., Woods, J. A., Bishop, N. C., Fleshner, M., et al. (2011). Position statement. Part one: immune function and exercise. Exerc. Immunol. Rev. 17, 6-63.

Waśkiewicz, Z., Kłapcinska, B., Sadowska-Krepa, E., Czuba, M., Kempa, K., Kimsa, E., et al. (2012). Acute metabolic responses to a 24-h ultra-marathon race in male amateur runners. Eur. J. Appl. Physiol. 112, 1679-1688. doi: 10.1007/s00421-011-2135-5

Wilhelm, M., Zueger, T., De Marchi, S., Rimoldi, S. F., Brugger, N., Steiner, R., et al. (2014). Inflammation and atrial remodeling after a mountain marathon. Scand. J. Med. Sci. Sports 24, 519-525. doi: 10.1111/sms.12030

Zaldivar, F., Wang-Rodriguez, J., Nemet, D., Schwindt, C., Galassetti, P., Mills, P. J., et al. (2006). Constitutive pro- and anti-inflammatory cytokine and growth factor response to exercise in leukocytes. J. Appl. Physiol. 100, 1124-1133. doi: 10.1152/japplphysiol.00562.2005

Conflict of Interest Statement: The authors declare that the research was conducted in the absence of any commercial or financial relationships that could be construed as a potential conflict of interest.

Copyright (c) 2017 Barros, Nascimento, Prestes, Nóbrega, Córdova, Sousa and Boullosa. This is an open-access article distributed under the terms of the Creative Commons Attribution License (CC BY). The use, distribution or reproduction in other forums is permitted, provided the original author(s) or licensor are credited and that the original publication in this journal is cited, in accordance with accepted academic practice. No use, distribution or reproduction is permitted which does not comply with these terms. 